\author{
A Thesis \\ Submitted to the Graduate Faculty \\ of the \\ North Dakota State University \\ of Agriculture and Applied Science
}

By

Mohammed Saad Alkhuriji

In Partial Fulfillment of the Requirements
for the Degree of
MASTERS OF SCIENCE

Major Department:

Animal Science

October 2015

Fargo, North Dakota 


\section{North Dakota State University}

Graduate School

Title

EVALUATION OF GLYCATED ALBUMIN AS A METABOLIC MARKER FOR MARBLING IN COMMERCIAL FEEDER CATTLE.

\section{By}

Mohammed Saad Alkhuriji

The Supervisory Committee certifies that this disquisition complies with North Dakota State University's regulations and meets the accepted standards for the degree of

\section{MASTER OF SCIENCE}

\section{SUPERVISORY COMMITTEE:}

Dr. Eric Berg

Chair

Dr. Kendall Swanson

Dr. Stefan Vetter

Dr. Pawel Borowicz

Approved:

$\begin{array}{cc}\frac{10 / 26 / 2015}{\text { Date }} & \text { Dr. Gregory Lardy } \\ & \text { Department Chair }\end{array}$




\begin{abstract}
This study was conducted to determine if glycated albumin is associated with marbling in beef cattle. Crossbred steers $(n=113)$ were assigned randomly to different treatments to determine the effects of feeding strategies (with anabolic growth implants, CONV; without growth implants, NAT) on blood proteins, glucose, and insulin. Total serum protein and albumin were not different between marbling scores and feeding strategies. Glycated albumin was not correlated with marbling scores. Plasma glucose concentration was greater in steers with a marbling score of slight compared to all other marbling scores, and NAT feeding strategy had greater concentration than $\mathrm{CONV}(\mathrm{P}=0.02)$. Plasma insulin in steers with marbling scores of modest and moderate were greater than small $(\mathrm{P}=0.01)$. However, they were all similar to marbling scores of slight and slightly abundant. More research is necessary to determine whether glycated albumin is associated with marbling in beef cattle.
\end{abstract}




\section{ACKNOWLEDGEMENTS}

First, I would like to thank Dr. Eric Berg for his guidance and support throughout my master's program. I also would like to thank my committee members, Dr. Kendall Swanson, Dr. Stefan Vetter, and Dr. Pawel Borowicz for their consultation and contribution to this thesis.

I would like to thank all of the faculty and staff in the NDSU Animal Sciences Department, and the staff of Dr. Vetter's lab. I also would like to thank all the animal sciences graduate students for their help and support.

Lastly, I would like to thank my family for their support because without this support, I would never have finished my master degree. Thank you very much. 


\section{TABLE OF CONTENTS}

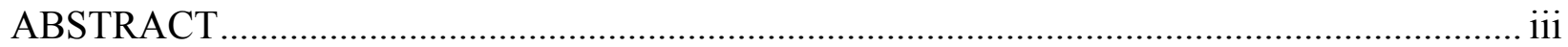

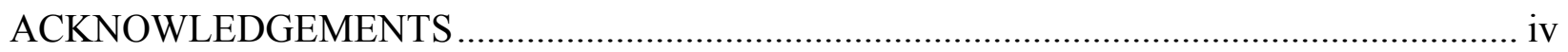

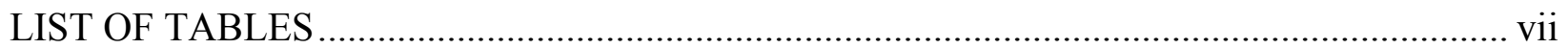

LIST OF FIGURES …............................................................................................. vii

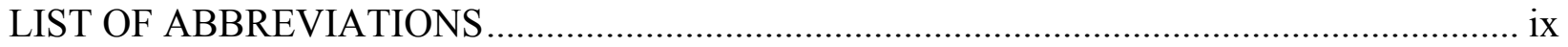

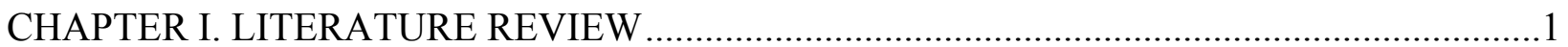

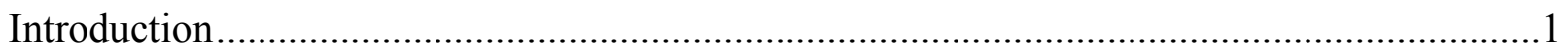

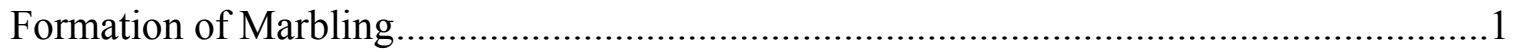

Factors That Influence the Formation of Marbling.....................................................5

Blood Markers for Estimating Marbling..................................................................... 16

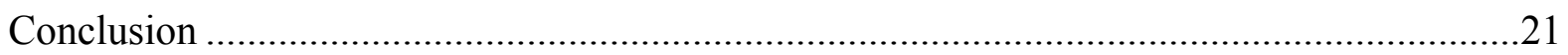

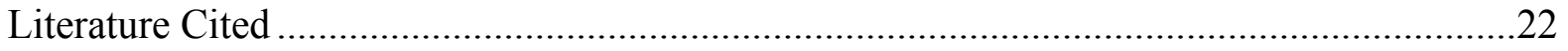

CHAPTER II. EVALUATION OF GLYCATED ALBUMIN AS A METABOLIC MARKER FOR MARBLING IN COMMERCIAL FEEDER CATTLE ....................................................33

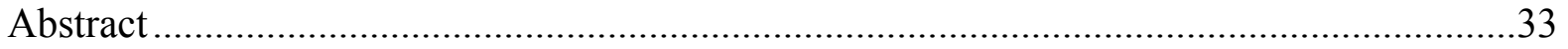

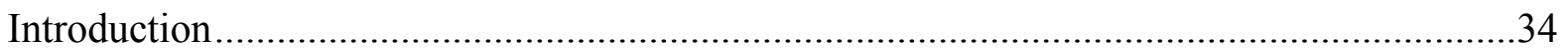

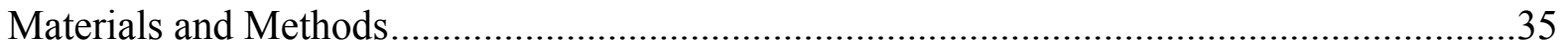

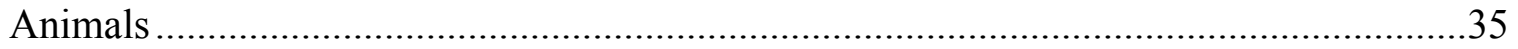

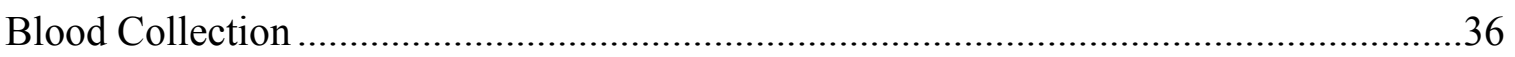

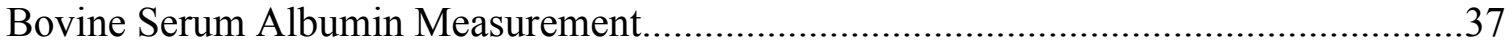

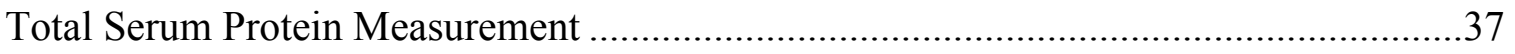

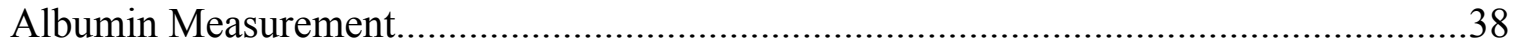

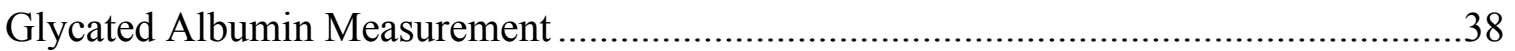


Statistical Analysis

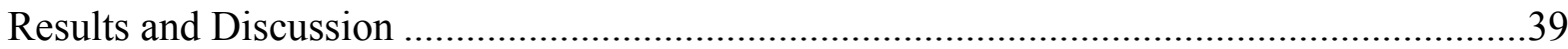

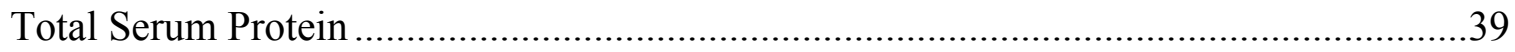

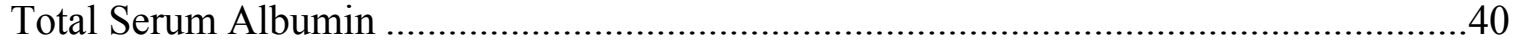

Total Serum Glycated Albumin ...........................................................................42

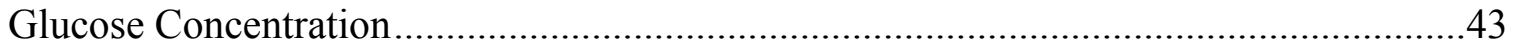

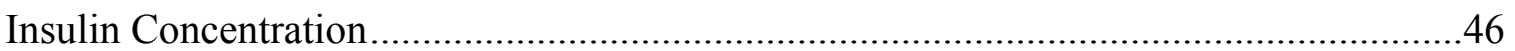

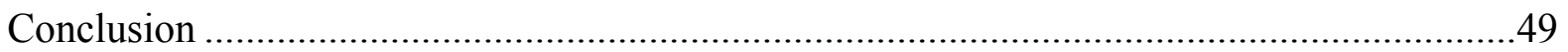

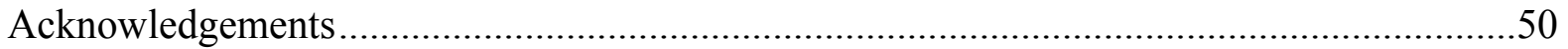

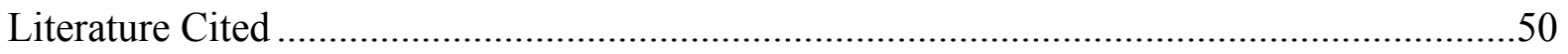




\section{LIST OF TABLES}

$\underline{\text { Table }}$

$\underline{\text { Page }}$

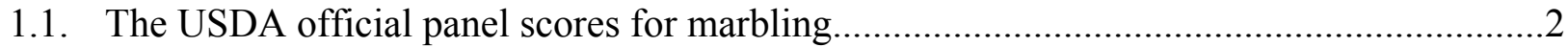

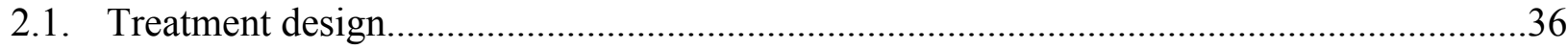

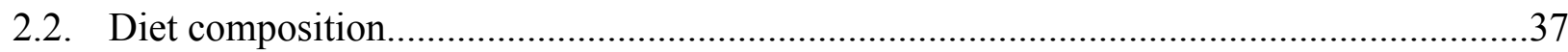

2.3. Mean, standard deviation, and range for carcass parameters and blood metabolites collected after 140 days on feed

2.4. Influence of feeding strategy on carcass parameters and blood metabolites collected after 140 days on feed

2.5. Pearson correlation coefficients for Marb, KPH, REA, FD12, T-SP, T-SA, T-GA, and P-GA.

2.6. Least squares means (standard error) for blood metabolites across USDA official marbling score.

2.7. Glucose concentration $(\mathrm{mg} / \mathrm{dL})$ over day and marbling score.....................................44

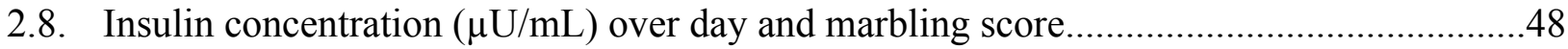




\section{LIST OF FIGURES}

Figure $\quad$ Page

1.1. Intramuscular fat development in beef cattle............................................................

2.1. Serum glucose concentrations for degree of marbling, and for 140 days........................46

2.2. Serum glucose concentrations for feeding strategies, and for 140 days..........................46

2.3. Serum insulin concentrations for feeding strategies, and for 140 days...........................49

2.4. Serum insulin concentrations for feeding strategies, and for 140 days..........................49 


\section{LIST OF ABBREVIATIONS}

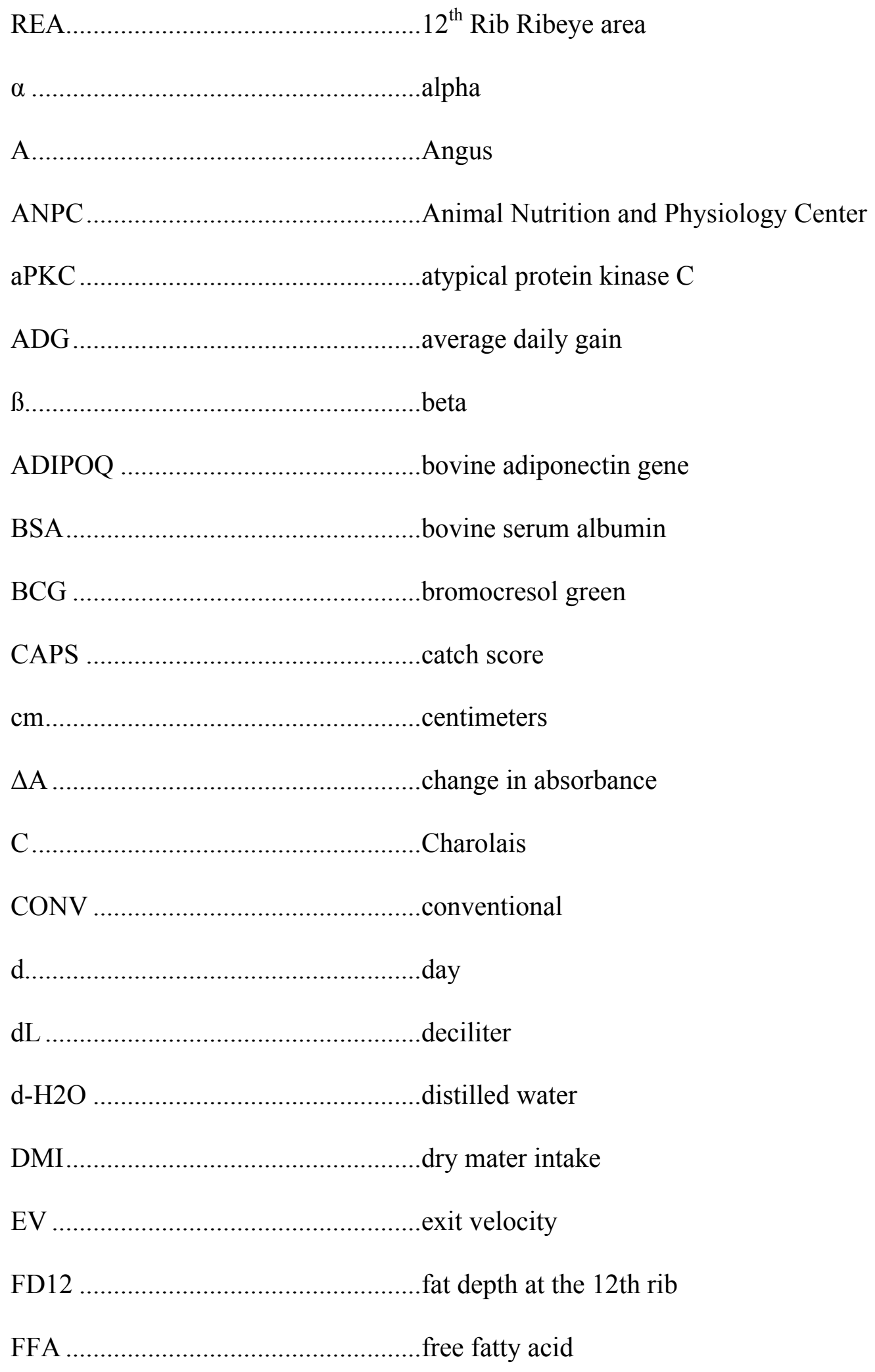




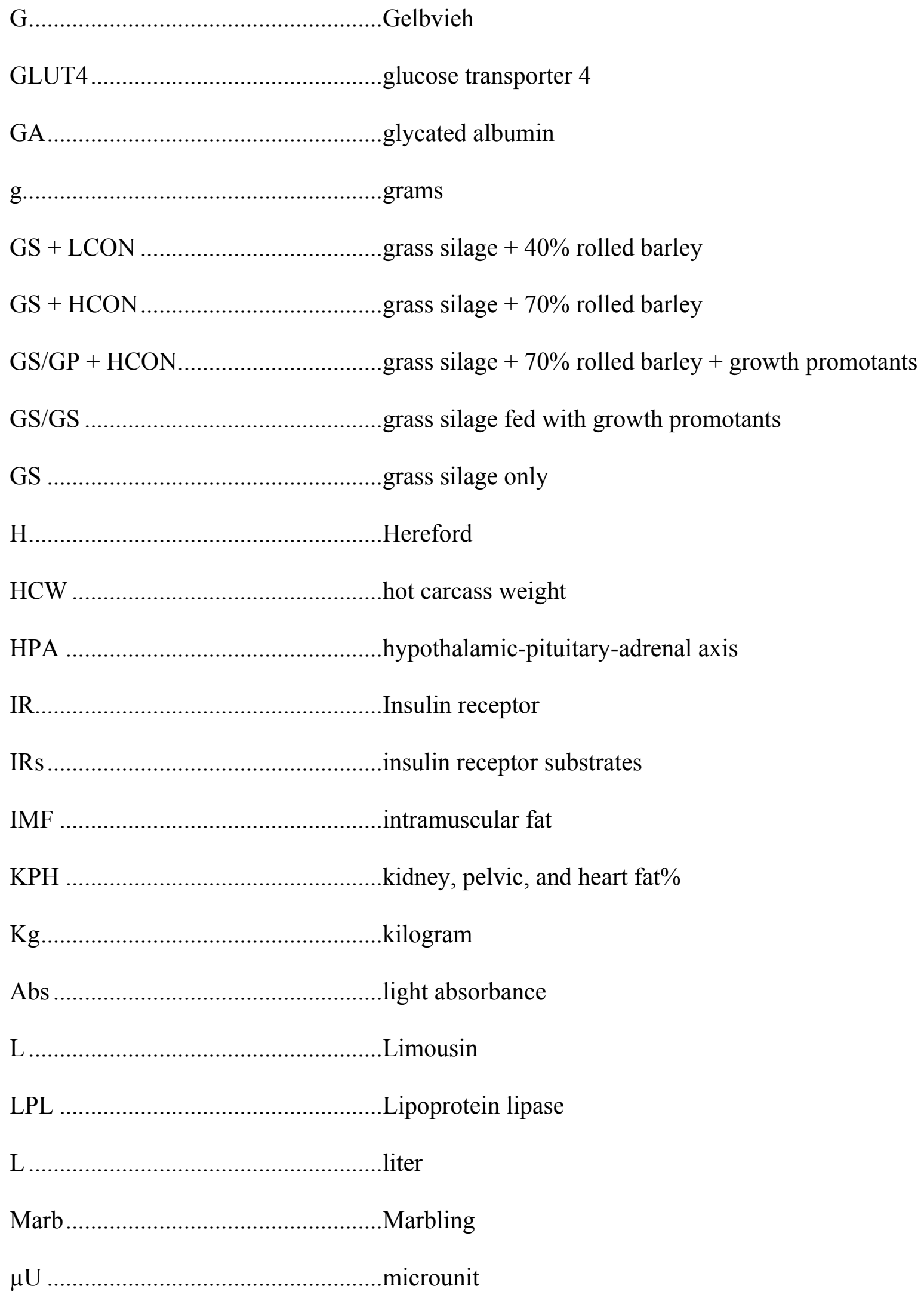




mE


SAND ..............................................vitamin A with no supplemental vitamin D

NASD ...............................................vitamin D with no supplemental vitamin A

WBSF..............................................Warner-Bratzler shear force 


\section{CHAPTER I. LITERATURE REVIEW}

\section{Introduction}

The following sections review current literature on formation of marbling, factors that influence its formation, and the potential for estimating marbling (or capacity to deposit marbling) via blood markers. The main objective of the current research was to evaluate glycated albumin as a metabolic marker for marbling in commercial feeder cattle.

\section{Formation of Marbling}

Marbling is a term used in the beef industry referring to flecks of intramuscular fat (IMF) between the muscle fibers bundles. The amount of IMF plays an important role in the overall quality of meats. Marbling is one of the most important meat quality characteristics because it positively correlates with and influences flavor and juiciness that directly contribute to the wholesale commodity price of U.S. beef (Harper et al., 2004; Killinger et al., 2004). In the retail and foodservice sector, some beef consumers are willing to pay more for beef possessing more marbling which is directly related to a higher USDA quality grade (Platter et al., 2005). Increasing the IMF also enhances the palatability of beef (Umberger, et al., 2000). Due to the high demand for marbled meats, marbling has been a priority for the U.S. beef industry. The USDA has established a marbling score panel reported in degrees from low to high presence of IMF (Table 1.1). A trained USDA grader determines the degree of marbling. Anatomically, IMF content is evaluated within the cut lean surface of the longissimus thoracis at the $12^{\text {th }}$ and $13^{\text {th }}$ thoracic rib interface of the beef carcass side.

There are four commonly described locations for fat formation (adipogenesis) in mammalian species: 1) visceral, 2) subcutaneous, 3) intermuscular, and 4) intramuscular. (Hausman et al., 2009; Du et al., 2011). Visceral and subcutaneous fat (SQ) deposition develops 
quicker than IMF and has a negative correlation with beef carcass value because these sites account for the majority of carcass fat that is delivered to rendering and possesses little value. Likewise, intermuscular adipogenesis develops next as the adipose accumulates between the seams of muscle. Therefore, the age of the animal plays an important role on marbling formation, because marbling (IMF) is the last adipose tissue deposited in finishing animals even though adipogenesis begins during fetal development (Du et al., 2011; Hocquette et al., 2009).

Table 1.1. The USDA official panel scores

\begin{tabular}{lc} 
for marbling (USDA, 1997). \\
\hline Degree of Marbling & Marbling Score \\
\hline Practically Devoid & 100 \\
Traces & 200 \\
Slight & 300 \\
Small & 400 \\
Modest & 500 \\
Moderate & 600 \\
Slightly Abundant & 700 \\
Moderately Abundant & 800 \\
Abundant & 900 \\
\hline
\end{tabular}

The commitment and expression of adipocytes occur during fetal development and the adipocyte numbers are fixed in the body by late adolescence. During the second trimester of bovine fetal development, the adipocytes in visceral and SQ depots start to form; however, the formation of adipocytes in the intermuscular fat depots is barely detectable (Du et al., 2011). During the postnatal growth period, new adipocytes are formed, but fat accumulation is mainly due to the increase in adipocyte size (adipocyte hypertrophy; Figure 1.1). Researchers have shown that accumulation of IMF (marbling) is due to hypertrophy of adipose cells, which is the main mechanism during the fattening stage (Hood, 1982). 


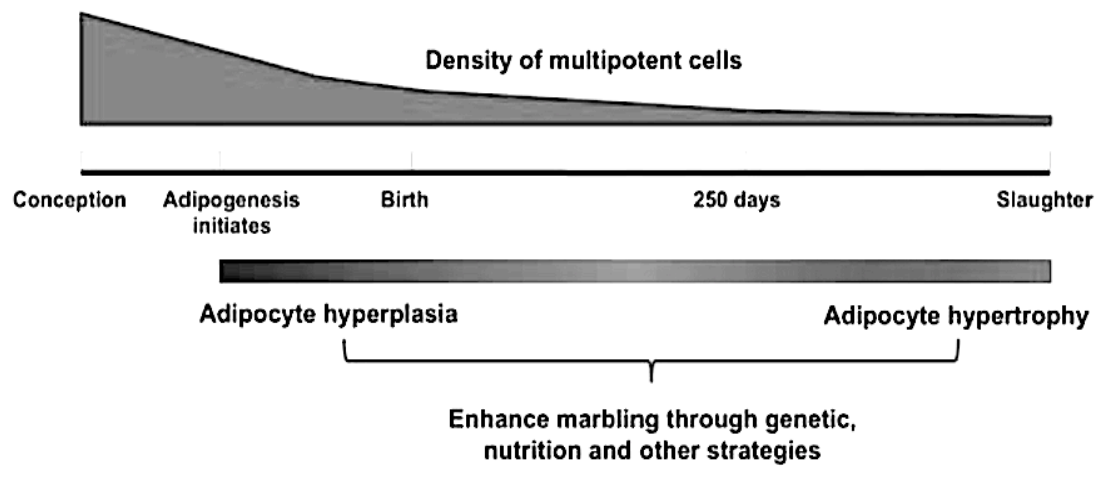

Figure 1.1. Intramuscular fat development in beef cattle (Du et al., 2011).

There are many studies focused on meat marbling due to the fact that marbling is so critical to meat quality and value. Scientific studies have focused on enhancement, development, and measurement of marbling, in addition to palatability of marbled meat. For example, a study on marbling enhancement by Leheska et al. (2008) found that cattle finished in the feedlot had more marbling than grazed cattle. Several studies by Wood et al. (2008), Daley et al. (2010), and Cifuni et al. (2004) focused on formation adipose, sites of deposition, and the fatty acids profile of intramuscular fat of different cuts of beef.

Other research has focused on the objective measurement of marbling because marbling is the principal component for classification of USDA quality grade and carcass valuation. For example, Yang et al. (2006), utilized computer image analysis to measure the intramuscular adipocytes in the longissimus muscle of beef cattle. In addition, Bonnet et al. (2007) showed that leptin, a protein hormone produced via adipocytes, was associated with the expression of marbling. Regarding palatability, a study by Corbin et al. (2015) demonstrated that IMF content had a positive influence on meat flavor perception. In addition, high IMF content was positively associated with consumer acceptability. 
Because marbling plays an important role on beef carcass value, it directly influences the profitability of beef cattle production (Andrews et al., 2007). To understand the effect of marbling on beef cattle profitability, a study by De Matos (1994) investigated the affect of beef carcass characteristics (such as marbling, hot carcass weight, and muscle score) on market value. The results of the study revealed a significant positive correlation between marbling score and final carcass value.

Platter and colleagues (2005) evaluated the effects of marbling score and Warner-Bratzler shear force (WBSF), a mechanical estimate of beef tenderness (Caine et al., 2003), on consumer purchasing behavior and the desire to pay for beef strip loin steak. Marbling score and WBSF of 541 beef strip loin steaks were measured and 489 consumers were included in the study. To measure willingness to pay for the different steaks, consumers were asked to bid and chose from steaks presented in a simulated retail display. Bid prices for steaks were analyzed with respect to changes in steak marbling score, USDA quality grade, and WBSF value (tenderness). The researchers concluded that an increase in marbling score and tenderness resulted in an increased willingness to purchase price and pay a premium price.

We have already established that IMF is the last fat depot deposited in livestock. It is critical for a beef producer to market cattle when IMF is maximized and SQ is minimized. The reason this timing is so critical is because IMF and SQ are inversely related to carcass value. A high marbling score increases the USDA quality grade and increases carcass value. Increased deposition of SQ results in a higher USDA yield grade that results in discounts in carcass valuation. Therefore, it would be of great benefit to the beef producer to identify a predictor (or "marker") to apply for estimating marbling score before slaughtering. 
Plasma glucose concentration (Matsuzaki et al., 1997), plasma insulin concentration (Trenkle and Topel, 1978), and insulin response to glucose challenge (Mir et al., 2002) and their association to marbling fat have been investigated previously. The relationship between plasma insulin, plasma glucose concentration, and degree of marbling in these trials was not well established and the authors suggested that further studies were needed to fully understand the role of insulin and glucose concentrations in the formation and development of IMF (Matsuzaki et al., 1997; Mir et al., 2002). Our hypothesis is that cattle receiving a high starch finishing diet will slowly become hyperglycemic. We further hypothesize that hyperglycemia will lead to hyperinsulinemia and tissue-specific down-regulation of insulin receptors on the glycogen saturated muscle cell. The insulin receptors of adipocytes remain viable so blood glucose is converted to triglycerides (TG), insulin binds its receptor on the adipocyte to assist the clearance and storage of TGs in adipocyte, increasing adiposity. While this is happening, circulating glucose begins to bind covalently with other proteins such hemoglobin and albumin. Quantifying the level of one or more of these glycated proteins could serve as a metabolic indicator of market readiness. Therefore, in the current study we evaluated glycated albumin as a metabolic marker for marbling in commercial feeder cattle.

\section{Factors That Influence the Formation of Marbling}

There are several factors that influence meat quality. These factors can be categorized into two different groups. The first group are factors linked directly to the animal such as genetics, breed, and sex while the second group are factors representing an external impact on the animal such as diet and living environment (Priolo et al., 2001). Therefore, this section will review the effects of these factors on degree of marbling in meat. 


\section{Genetics}

Genetics have been the focus of many new research studies. Discovering and understanding the genomic sequence of beef cattle has helped the beef industry increase profitability due to the high demand for high quality beef. There are several studies that have focused on identifying specific genes responsible for beef quality traits such as marbling and tenderness (Hocquette et al., 2007). The genes encoding $\mu$-calpain, lysyl oxidase, and calpastatin have been associated with tenderness (Hocquette et al., 2007). Hocquette et al. (2007) associated the genes encoding leptin, diacylglycerol acyl transferase 1, thyroglobulin, retinoic acid receptorrelated orphan receptor $\mathrm{C}$, growth hormone, stearoyl-CoA desaturase-1, mitochondria, mitochondrial transcription factor A, and fatty acid binding protein 4 with marbling. Another study by Choi et al. (2015) focused on validating genetic effects of the bovine adiponectin (ADIPOQ) gene on carcass traits such as marbling score, backfat thickness, ribeye area, and carcass weight of Hanwoo cattle. The authors concluded that the ADIPOQ gene was associated with marbling score in Hanwoo cattle. With further knowledge and understanding, sires possessing genes that enhance beef quality traits could be incorporated into breeding or rearing programs.

\section{Breed}

The breed of a particular species plays an important role on marbling deposition and other carcass traits. Breed associations have conducted sire progeny testing for decades in an effort to identify sires with the best genetic potential for economically important carcass traits. Dairy, rustic, dual-purpose, double muscled, and meat breeds have all shown differences in carcasses traits (Campo et al., 1998). A study by Cuvelier et al. (2006) evaluated the chemical composition and fatty acid content in the Longissimus thoracis muscle from three different 
breeds; Belgian Blue, Limousin, and Aberdeen Angus. The Angus bulls had the greatest content of marbling and the Belgian Blue bulls had the least. The authors concluded that Aberdeen Angus bulls produced the greatest level of IMF and suggested consumers looking for leaner beef should choose beef from the Belgian Blue breed of cattle. In a larger study by Wheeler et al. (2005), carcass traits were evaluated and compared between different cattle breeds. Dams of Hereford (H), Angus (A), and MARC III (1/4 Angus, 1/4 Hereford, 1/4 Pinzgauer, and 1/4 Red Poll) were mated via artificial insemination with Angus, Hereford, Red Angus (RA), Charolais (C), Limousin (L), Simmental (S), and Gelbvieh (G) bulls to produce 649 steer calves. All steers were raised in the same location and fed the same diet. The results of this study showed that A- and RA-sired steers had the greatest yield grade and L- and C-sired had the lowest. Moreover, Angus- and RA-sired steers had the greatest marbling scores and L- and G-sired had the lowest. Angus- and RA-sired steers had the greatest percentage of USDA choice grade and L- and Gsired had the lowest. The authors concluded that European breeds (C, L, S, and G) are leaner and heavier muscled than British breeds (H, A, and RA) and possessed less marbling than A or RA.

Another study by Chambaz et al. (2003) estimated the effect of breeds on beef cattle traits. The study utilized four different breeds: Angus, Simmental, Charolais, and Limousin reared under similar conditions. The results of the study did not show significant differences in marbling score except for the Angus breed. Angus were significantly greater in marbling when compared with the other breeds. The authors of the study concluded that Charolais and Limousin would provide heavier carcasses but would require an unusually long fattening period. Therefore, intensive fattening systems would be preferred. Angus beef would give shorter fattening period and provide the best choice for extensive fattening systems. Because the Simmental beef was ranked less favorable in beef quality, the authors suggested that crossbreeding might improve the 
Simmental offspring's beef quality. Beef cattle producers must be aware how different breeds of cattle (and sires within breeds of cattle) could influence their products.

\section{Sex}

Sex is one of the many factors directly linked to beef carcass characteristics. Certain sexspecific hormones have been shown to impact meat quality (Hartwig et al., 1997). The National Beef Quality Audit (Moore et al. 2011) investigated the effect of sex on beef cattle traits. In this survey, sex was classified into four different groups: steer, heifer, cow, and bullock (a bull that castrated in older age). The distribution was $63.47 \%$ for steers, $36.37 \%$ for heifers, $0.13 \%$ for cows, and $0.03 \%$ for bullocks. The results indicated that steers and bullocks had similar hot carcass weight $(\mathrm{HCW})$; steers had greater $\mathrm{HCW}$ than heifers and cows, but bullock, heifers, and cows had similar HCW. Both steers and heifers had similar USDA quality grade score, yet were greater score than that of cows and bullocks. For the overall maturity, both steers and heifers were younger than cows and bullocks. Heifers had the greatest marbling score and bullocks had the lowest score. Cows had similar marbling score when compared with steers and heifers. Moreover, steers had significantly greater marbling score than bullocks. In another study by Park et al. (2002), sex was evaluated to determine its effects on beef quality. The study utilized 20,881 Hanwoo cattle, which is a native Korean cattle breed. Sex was classified into three different groups; steers, bulls, and cows. The distribution of carcasses was $31.44 \%$ for steers, $28.80 \%$ for bulls, and $39.75 \%$ for cows. They found steers and bulls had similar overall maturity, but both were younger than cows. Steers had the greatest HCW and cows had the lowest. For the marbling score, steers had the greatest marbling score when compered with bulls and cows, while cows had more marbling than bulls. The authors concluded that quality grades of steer carcasses were greater than cow or bull carcasses. Another two experiments conducted by Choat 
et al. (2006) evaluated the effects of cattle sex on carcass characteristics and longissimus muscle palatability. In both experiments, animals were of similar age and were fed similar feed. In the first experiment, 99 steers, 51 heifers, and 46 intra-vaginally spayed heifers were utilized. In the first experiment, heifers, either intact or spayed, were similar but had significantly more marbling than steers. Moreover, heifers had a significantly greater USDA quality grade than steers. In the second experiment, 60 steers and 60 intact heifers were utilized. Both steers and heifers had similar marbling score and USDA quality grade. Choat et al. (2006) suggested that sex should be added to the list of antemortem factors contributing to variation in beef quality.

\section{Feeding}

Feed is one of the most important factors influencing beef quality. Scientists have investigated factors that decrease or increase beef quality such as feeding regimes (grain fed vs. grass fed; Leheska et al., 2008), the use of growth-enhancing implants (Gerken et al., 1995), and the use of vitamin supplements (Hocquette et al., 2009).

Feeding Strategies. Feeding regimens have a big impact on meat quality. The composition of the diet fed can result in a change in the fatty acid profile of the meat by decreasing or increasing the saturated to unsaturated fatty acid ratio, as well as changethe fat color. The diet fed may also decrease intramuscular fat deposition and thus influence meat quality (flavor and juiciness.) and the subsequent USDA quality grade (Daley et al., 2010).

A study by Leheska et al. (2008) evaluated the effects of grain and grass-feeding regimes on beef quality. Samples of ground beef and strip lions were taken from beef fed either grain or grass. The results showed that feeding a grass diet to beef cattle in the finishing period could lead to a reduction in degree of marbling when compared to beef cattle fed a grain diet. This could be due to the lower energy consumed in the grass fed system. In addition, the carcass fat from the 
grass fed cattle tended to be more yellow compared with the grain fed diet. This change in color could be explained by the change of fatty acid profiles in the grass fed diet when compared to the grain fed diet or it could be due to the greater level of some vitamins consumed in the grass fed diet such as $\beta$-carotene, which gives fat a yellowish color (Daley et al., 2010). Another study by Faucitano et al. (2008) compered the effect of beef production systems based on forage finishing or grain-forage diets on meat quality and fatty acid composition. Forty head of Angus cross steers were raised on five different diets; 1) grass silage only (GS), 2) grass silage fed to cattle that received growth promotants (GS/GP), 3) grass silage $+40 \%$ rolled barley $(\mathrm{GS}+\mathrm{LCON}), 4)$ grass silage $+70 \%$ rolled barley $(\mathrm{GS}+\mathrm{HCON})$, and 5$)$ grass silage $+70 \%$ rolled barley + growth promotants $(\mathrm{GS} / \mathrm{GP}+\mathrm{HCON})$. The results of this study did show a significant difference in IMF content between the diets that contained concentrates (barley), either GS + LCON or GS + HCON, when compared with GS. The GS diet had the lowest content of IMF. The marbling score of carcasses from cattle that received growth promotants were not significantly different than the other diets. Moreover, there was no interaction seen between growth promotants and rolled barley concentrates. The authors concluded that grain fed regimen tended to increase marbling and saturated fatty acids, which could be of interest to beef producers who invest to produce natural beef that meets the quality demands of health-conscious consumers.

Growth Promoting Technology. Growth-enhancing implants have been used widely in the U.S. beef industry. Implants can be classified as estrogenic, androgenic, or a combination. These implants have been utilized to enhance the rate of growth and feed efficiency of growing beef cattle by improving nitrogen retention via protein synthesis in muscle cells (Nichols et al., 2002). A study by Gerken et al. (1995) investigated the application of estrogenic, androgenic, and combination implants on genetically identical Brangus steers. They discovered that implants 
had no effect on marbling score. Another study by Smith et al. (2006) investigated the application of the combination of estrogenic and androgenic implants on Angus steers and heifers. The results showed that there was no significant difference in marbling score in either the steers or heifers. Both Gerken et al. (1995) and Smith et al. (2006) reported that the use of cattle with great genetic potential to deposit intramuscular fat (marbling) could explain why marbling score did not change between treatments. However, in a different study by Mader (2000), the use of estrogenic, androgenic, or combination implants on heifers decreased marbling score and increased the ribeye area when compared to the control treatment where heifers did not receive implants. In addition, a study by Hershler et al. (1995) investigated the use of estrogenic, androgenic, or combination implants in various doses on steers and heifers. Their results indicated that androgenic implants had no effect on the marbling score when compared to the control steers; however, the use of estrogenic or the combination of estrogenic and androgenic implants decreased marbling score when compared with controls. When the same treatments were applied to heifers, all implants decreased marbling score compared to controls, however the use of low doses of combination estrogenic and androgenic created a difference. Duckett et al. (1997) reported a negative correlation between marbling score and ribeye area. Therefore, when growth promotants lead to an enlargement of the ribeye, marbling score tends to decrease. In conclusion, growth-enhancing implants should be taken under consideration when thinking about producing lean beef cattle.

Vitamin and Mineral Supplementation. Because marbling is one of the major factors involved in determining USDA Quality grades and carcass value, beef production systems have been continually investigating ways to increase degree of marbling in feedlot cattle (USDA, 1997). Vitamin supplementation has been investigated to understand its relationship with IMF 
deposition and USDA Quality grades. Increasing supplementation of vitamin A and D has been shown to inhibit adipocyte differentiation and fat accumulation within the cells (Pyatt et al. 2005). That said, restricted quantities of these vitamins may actively stimulate fat deposition (Pyatt et al. 2005). A study by Pickworth et al. (2012) investigated the restriction or supplementation of vitamin $\mathrm{A}$ and $\mathrm{D}$ in beef cattle finishing diets on performance and meat quality. The study was conducted utilizing 168 Angus crossbred steers, which were randomly assigned to 1 of 4 treatments. The treatments were as follows: no vitamin A or D supplementation (NAND), vitamin A with no supplemental vitamin D (SAND), vitamin D with no supplemental vitamin A (NASD), and vitamin A and D supplementations (SASD). The results of this investigation showed that the SASD and SAND treatments altered retinol concentration of SQ and IMF adipose tissue depots, which resulted in a lower marbling score when compered with NAND. The NASD treatment had a lower impact on carcass composition when compered with NAND. Pickworth et al. (2012) concluded that removing vitamin A from a $184 \mathrm{~d}$ finishing period may improve marbling scores and USDA quality grade. Another study by Gorocica-Buenfil et al. (2007) evaluated the effect of dietary vitamin A supplementation on marbling. Angus crossbred steers $(n=168)$ were randomly assigned to two diets; one with vitamin A supplementation and the other without. The feeding period was divided into 2 periods. The first period was the backgrounding period ( 84 days) and the $2^{\text {nd }}$ period was the finishing period (168 days). The purpose of the backgrounding period was to allow time for the depletion of vitamin A from hepatic cells. There was a tendency for the absence of vitamin A to increase carcass USDA quality grade because it affected degree of marbling, shifting from small to modest. Therefore, the authors concluded that the restriction of vitamin A supplementation might increase IMF depot as suggested by the trend for greater USDA quality grades and marbling 
scores. It is very obvious that some vitamins have impact on beef quality and should be taking into consideration when attempting to enhance IMF and USDA quality grades.

\section{Chronic Stress}

Chronic stress can play an important role in carcass characteristics, and can be triggered by different factors such as environmentally or handling. Stress caused by handling such as transport, mixing, and time off feed and water can trigger the hypothalamic-pituitary-adrenal axis (HPA), which causes a hormonal response to maintain the homeostasis of an animal (Café et al., 2011; Hall et al., 2011). The behavioral response to a stressor in cattle (temperament) can influence carcass characteristics and higher temperament has been linked to reduction in carcass traits (Hall et al., 2011).

Temperament. Cattle with excitable temperament have been known to produce more glucocorticoids, which is the endpoint of the response of HPA during a stressful event (Curley, 2004; King et al., 2006). Glucocorticoids such as cortisol are the primary hormone during a stressful event and play an important role on glucose homeostasis. Curley (2004) showed that because energy may be needed during a stressful event, glucocorticoids increase the activity of glucagon and gluconeogenesis. Therefore, during a prolonged stress respond, animal growth is compromised because maintenance becomes a higher priority than growth and development via limiting the available energy from unnecessary body processes such as fat storage.

Hall et al. (2011) evaluated the working chute behavior of feedlot cattle as an indication of cattle temperament. This study utilized 183 commercial crossbred Bos taurus steers. All steers were of similar age and fed the same diet. During each weigh period, exit velocity (EV), chute score, and catch score (CAPS) were measured to indicate the steers' temperament. The results of the study indicated that steers became used to the chute environment because they exited more 
slowly and CAPS decreased over time. Moreover, steers with lower CAPS were calmer and had greater marbling score. Ribeye steaks from steers with lower EV score had lower WarnerBratzler shear force (more tender meat). The authors concluded that steers with lower tolerance of the working chute environment might possess lower carcasses quality.

Temperature. Chronic heat can cause physiological stress to the animals. Chronic stress caused by the environment such as high temperature coupled with or without high humidity and solar radiation can decrease the animal's performance. For example, hyperphagia (increased consumption) increases metabolic rate. Metabolism generates $31 \%$ of the heat load of an animal, thus one of the first responses to heat stress is a reduction of feed intake (Blackshaw and Blackshaw, 1994). This reduction in feed intake leads to an increase need for maintenance energy in an effort to balance heat production with heat loss; and thus may have a negative impact on carcasses characteristics because the animal does not receive the daily requirement in order to gain more weight and deposit fat (Blackshaw and Blackshaw, 1994). These changes in adaptive physiology could also drop the value of the beef carcasses dramatically; so avoiding such conditions is critical (Mader and Davis, 2004).

A study by Mitlöhner et al. (2002) examined the impact of shaded pens verses unshaded pens on 168 heifers' performance and carcass characteristics. The results of this study showed that shaded heifers had greater final body weights and hot carcass weights compared to unshaded heifers. This can be explained by the fact that heat stress alters neurons to send a signal to the hypothalamus, which causes numerous physiological, anatomical, or behavioral changes in order to maintain heat balance. Feed intake reduction is one of the responses, which occurs during heat stress (West, 2003). This can be proved by the fact that shaded heifers had greater dry mater intake (DMI) and greater average daily gain (ADG) when compared with unshaded heifers. In 
the same study, marbling score did not differ between shaded and unshaded heifers; however, the dressing percent and USDA yield grade were greater in shaded heifers. The incidence of darkcutting carcasses, caused by a high steady-state postmortem $\mathrm{pH}$ (Miller, 2007), can lead to the reduction of the USDA quality grade. The unshaded heifers had a greater percentage of darkcutting carcasses compared with carcasses from shaded heifers. This could have been the result of reduced feed consumption. Prolonged heat stress causes feed intake reduction, which could lead to glycogen deficiency. Postmortem anaerobic glycolysis glycogen glucose molecules are known to reduce $\mathrm{pH}$ in muscle after slaughter. However, when glycogen deficiency occurs, muscle $\mathrm{pH}$ remains elevated and so does mitochondrial respiration, which in turn can deoxygenize myoglobin and result in dark red lean color (Kreikemeier et al., 1998). Another study by Gaughan et al. (2010) conducted in Queensland Australia, utilized 164 Angus steers to evaluate the effect of shade on performance and carcass characteristics. The results of this study were similar to the results of Mitlöhner et al. (2002). The ADG and DMI were greater in the shaded steers when compared with unshaded steers. In addition, final body weights and hot carcass weights were greater in the shaded steers when compared with unshaded steers. The marbling score did not differ between shaded and unshaded steers. However, a study by Mader et al. (1999) showed different results. They examined shade and wind barrier effects on summertime feedlot cattle performance. This study consisted of four different treatments. Treatments were as follows: shaded pens with or without wind barrier and unshaded pens with or without wind barrier. The ADG, DMI, and final body weight did not differ between treatments. Nor did carcass dressing percent, USDA yield grade, and marbling score. 


\section{Blood Markers for Estimating Marbling}

Finding an accurate and convenient marker to apply for estimating degree of marbling before slaughter is critical. There are a few studies that have focused on identifying a method for the measurement of marbling. Lipoprotein lipase (LPL), leptin, plasma glucose concentration, and plasma insulin concentration have been investigated previously (Trenkle and Topel, 1978; Matsuzaki et al., 1997; Wegner et al., 2001; Kazala et al., 2002).

Lipoprotein lipase is an enzyme produced in many mammalian tissues. Lipoprotein lipase is a cleaning enzyme that hydrolyzes triglyceride (TG) molecules to liberate free fatty acids from (for example) circulating lipoproteins such as very low-density lipoprotein (VLDL) and chylomicrons molecules. These free fatty acids are assimilated by muscle (used as an energy source) and adipose tissues (reesterified and stored; Goldberg, 1996). Lipoprotein lipase activity differs between different tissues such as myocytes or adipocytes (Albalat et al., 2007). Lipoprotein lipase is highly regulated via insulin in adipocytes; however, insulin decreases the activity of LPL in myocytes when oxidation of glucose is sufficient (Jindrichova et al., 2001). Studies showed that during fasting, LPL activity is down regulated in adipocytes but it does not change in myocytes. In addition, during the refeeding period, LPL activity increases in adipocytes in order to store energy (Botion, 2001; Albalat et al., 2007). The relationship of LPL with insulin resistance has not always been consistent (Corcoran et al., 2007). For example, Ferreira et al. (2001) showed that overexpression of muscle LPL in mice caused insulin resistance because of the accumulation of IMF. However, Voshol et al. (2001) showed that overexpression of muscle LPL in mice did not decrease muscle glucose uptake.

Several research studies have investigated the role of LPL on fat accumulation during intense feeding. A study by Voshol et al. (2001) evaluated the content of TG in mice muscle. 
Male mice with muscle-specific overexpression of human LPL and control male wild-type mice were utilized in the study. Both groups of mice were fed and raised under the same conditions. Results of the study showed a significantly greater TG accumulation in the mice with musclespecific overexpression of human LPL when compared with the control group. In addition, content of TGs in hepatic cells and plasma concentration of TGs were significantly lower than those of the control group, which were caused by the high activity of LPL. Consequently, their findings support the role of LPL in TG accumulation in the IMF. In another study, Sato et al. (1999) studied the role of isolated monoclonal antibodies, which inhibit the function of LPL in the reduction of fat accumulation in broiler chickens. The LPL antibodies were chronically infused in 4-week-old male broiler chickens for 7 days prior to harvest. The results obtained from this study showed that LPL antibodies inhibited the VLDL hydrolysis by LPL in vitro and in vivo, and the chronically infused male broiler chickens had lower fat accumulation when compered with the controls. Hence, these results are in agreement with the role of LPL in fat accumulation.

Leptin is a protein-hormone that is secreted by adipocytes and assists in the regulation of feed intake and energy balance. Leptin is highly correlated with body fat mass and adipocyte size because it metabolically influences fat deposition in both animals and humans (Xie et al., 1999). Several studies have demonstrated the relationship between circulating leptin concentration and degree of marbling in beef cattle. A study by Bonnet et al. (2007) evaluated the correlation between leptin and degree of marbling among Limousin $(\mathrm{n}=12)$, Japanese Black $\times$ Angus $(\mathrm{n}=$ 10), and Angus $(\mathrm{n}=10)$ steers. Steers were grown and fed in the same conditions. Dissected IMF from the LT muscle and subcutaneous adipocyte samples were used to measure the level of mRNA expression of leptin. The results of the study did show a significant difference between 
breeds in the level of mRNA expression of leptin. Angus steers had greater levels of leptin mRNA when compared with the other breeds. Moreover, Angus also had greater content of IMF. Therefore, the authors concluded that leptin could be related to the expression of marbling. Another study by Geary et al. (2003) utilized leptin as a predictor of carcass composition in beef cattle. Eighty-eight head of $1 / 2$ Red Angus, $1 / 4$ Charolais, and $1 / 4$ Tarentaise composite gene combination steers were used in the study. Steers were grown and fed under the same conditions. The results of the study showed a positive correlation between leptin concentration and degree of marbling, kidney, pelvic, and heart fat (KPH), USDA quality grade, fat depth at the $12^{\text {th }}$ rib (FD12), and calculated yield grade. Therefore, the authors concluded that leptin might be a valuable tool for the measurement of degree of marbling, which can be applied before harvest and give an indicator of the carcass value. However, another study by Wegner et al. (2001) examined the relationship between leptin concentration and IMF in beef cattle with 0,50 and 75 percent Wagyu genetic influence. Animals with the Japanese Wagyu influence have been known for substantial marbling. Crossbred Wagyu steers $(\mathrm{n}=24)$ were examined including steers with 0 percent Wagyu genetic influence (Continental Crossbred), 50 percent (Wagyu $\times$ Angus or Simmental), and 75 percent (Wagyu $\times$ Angus, Holstein, or Simmental). The results of this study showed an increase in leptin level between the $0 \%$ Wagyu, 50\%, and 75\% Wagyu crossbred cattle. The $75 \%$ Wagyu cattle had the greater level of leptin. In addition, $0 \%$ Wagyu crossbred cattle showed a positive correlation between leptin level and LT muscle fat content. There was almost no correlation between leptin level and LT muscle fat content in the 50\% Wagyu crossbred cattle. However, the $75 \%$ Wagyu crossbred cattle showed a negative correlation between leptin level and LT muscle fat. Authors concluded that leptin has a positive correlation with marbling, but when the Wagyu genetics increase, a negative correlation might occur due to 
the breed influence on physiology of IMF deposition. In conclusion, leptin could serve as a valuable indicator of marbling before harvest yet more studies are needed to establish an accurate scale.

Glucose and insulin play an important role in the development of adipose tissues. Glucose is the preferred energy molecule and source for fat synthesis in muscle cells (Shingua et al., 2001). In addition, insulin is a key element in the regulation of lipogenic enzyme transcription, which is responsible for fat synthesis (Wong et al., 2010). Insulin also stimulates the uptake of glucose in myocytes and hepatocytes by activating glucose transporter 4 (GLUT4) and glucose transporter 2, respectively (Khan, 1998; Nordlie et al., 1999). Since hepatic and muscle tissues function as the storage site for circulating blood glucose, they become saturated with glucose/glycogen when a rich carbohydrate diet is chronically consumed resulting in hyperglycemia. Because muscle and liver tissues become saturated with glucose/glycogen in this stage, high insulin concentration may occur (hyperinsulinemia) and can lead to down-regulation of insulin receptors in target tissues such as myocytes, adipocytes, and hepatocytes causing insulin insensitivity (Wellnitz, 2013). Therefore, excess glucose in circulating blood is converted to fatty acids in the liver, formed into triglycerides, released into circulation, and ultimately stored in the adipose tissue (Carmen et al., 2006). Insulin receptor (IR) is a heterotetrameric tyrosine kinase receptor with two $\alpha$-subunits and two $\beta$-subunits (Wellnitz, 2013). In healthy, non-obese, and non-diabetic mammals, insulin binds to the two extracellular $\alpha$-subunits causing autophosphorylation of the insulin receptor substrates (IRS). After the phosphorylation of the IRS, phosphoinositide 3-kinase (PI3K) is recruited, which then catalyzes the formation of phosphoinositol lipids (PIPs). The formation of PIPs activates 3-phosphoinositide-dependent protein kinase-1, which then phosphorylates and activates atypical protein kinase $\mathrm{C}(\mathrm{aPKC})$ and 
protein kinase B Protein kinase B and aPKC mediate the translocation of the GLUT4 to the cell membrane in order to uptake glucose from circulation for glycolysis for energy or storage in glycogen (Corcoran et al., 2007). However, in case of muscle tissue-specific insulin resistance, which is caused by decrease in insulin-stimulated glucose uptake in skeletal muscle (Shanik et al., 2008), accumulation of IMF occurs (Kim et al., 2001). In order to understand such a mechanism, it is important to know that IRS contain numerous potential serine/threonine phosphorylation sites, which can prevent IRS from dissociation from IR and reduce the activation of PI3K (Corcoran et al., 2007). The accumulation of IMF is a result of increased free fatty acid (FFA) metabolites such as diacylglycerol. The increase in FFA metabolites activate particular isoforms of protein kinase $\mathrm{C}$, which can lead to the phosphorylation of IRS on the serine residues resulting in the reduction of PI3K activity (Delarue and Magnan, 2007). Therefore, identifying this physiological change may play an important role in accumulation of marbling because it could help to achieve a USDA Choice grade or higher while balancing against the accumulation of SQ fat, which could lead to discounts with USDA Yield Grade 4 or $5 \mathrm{~s}$.

A study by Mir et al. (2002) examined an intravenous glucose tolerance test (an insulin response to glucose challenge) and its association to marbling degree in three different breeds Wagyu, Wagyu $\times$ Limousin, and Limousin. The results of the study revealed that insulin response to intravenous glucose was lower in Limousin steers than in Wagyu steers, which was unexpected because the Wagyu breed tends to add more fat than the Limousin. Moreover, the authors concluded that the intravenous glucose tolerance test was not an appropriate indicator of marbling in the beef cattle observed in this study. T interfered with the measurement of light absorbance hey suggested further work was needed. Another study by Shingua et al. (2001) 
compared insulin secretion and glucose response to insulin in Japanese Black heifers (beef breed) compared with Holstein heifers (dairy breed). Japanese Black beef cattle are known for their high rate of IMF deposition. The study utilized 10 head of Japanese Black heifers and 10 Holstein. Insulin secretion did not differ between breeds from 1 to 12 months; however, after sexual maturation, Japanese Black heifers had higher insulin secretion than Holstein heifers. Both breeds had a similar glucose response to insulin. As insulin secretion in Japanese Black heifers was higher, this may have an impact on the amount of IMF.

Albumin is one of the most predominant proteins in the blood plasma. Synthesized in the liver, it is responsible for transfer of metabolic products, regulatory mediators, nutrients, and proteins from tissue to another. With chronic hyperglycemia, a non-enzymatic glycation of proteins may occur and glycated albumin $(\mathrm{GA})$ is one of the end products of protein glycation seen in circulation. Glycated albumin has been widely studied and has linked with metabolic disorders such as type 2 diabetes and cardiovascular disease (Anguizola et al., 2013; Zheng, et al, 2012; Zilg et al., 1979).

\section{Conclusion}

Marbling is one of the most important meat quality characteristics because it positively correlates and influences flavor, tenderness, and juiciness; it is also directly related to the value of beef in the US market. Degree of marbling is critical to the producer because it directly influences the USDA quality grade. Therefore, finding an easy reliable indicator of marbling before harvest is important, and because of that, our objective was to evaluate GA as a metabolic marker for marbling.

Our hypothesis is that hyperglycemia leads to hyperinsulinemia, which can induce tissuespecific down regulation of insulin receptors on muscle cells. These physiological changes can 
lead to intramuscular fat accumulation. Glycated albumin has not been evaluated as a metabolic byproduct associated with key physiological change in beef cattle that could lead to increased marbling deposition. In this study, GA was evaluated as a metabolic marker for marbling in beef cattle.

\section{Literature Cited}

Albalat, A., Saera-Vila, A., Capilla, E., Gutierrez, J., Perez-Sanchez, J., \& Navarro, I. (2007). Insulin regulation of lipoprotein lipase (LPL) activity and expression in gilthead sea bream (Sparus aurata). Comparative Biochemistry and Physiology Part B: Biochemistry and Molecular Biology, 148(2), 151-159.

Andrews, T., \& Littler, B. (2007). Market specifications for beef cattle. NSW DPI Primefacts'. Primefact, 621.

Anguizola, J., Matsuda, R., Barnaby, O. S., Hoy, K. S., Wa, C., DeBolt, E., ... Hage, D. S. (2013). Review: glycation of human serum albumin. Clinica Chimica Acta, 425, 64-76.

Blackshaw, J. K., \& Blackshaw, A. W. (1994). Heat stress in cattle and the effect of shade on production and behaviour: a review. Animal Production Science, 34(2), 285-295.

Bonnet, M., Faulconnier, Y., Leroux, C., Jurie, C., Cassar-Malek, I., Bauchart, D., ... Chilliard, Y. (2007). Glucose-6-phosphate dehydrogenase and leptin are related to marbling differences among Limousin and Angus or Japanese Black $\times$ Angus steers. Journal of Animal Science, 85(11), 2882-2894.

Botion, L. M. (2001). The influence of fasting/refeeding on the lipoprotein lipase activity of adipose tissue and muscle. Brazilian Journal of Medical and Biological Research, 34(11), $1411-1414$. 
Cafe, L. M., Robinson, D. L., Ferguson, D. M., McIntyre, B. L., Geesink, G. H., \& Greenwood, P. L. (2011). Cattle temperament: persistence of assessments and associations with productivity, efficiency, carcass and meat quality traits. Journal of Animal Science, 89(5), 1452-1465.

Caine, W. R., Aalhus, J. L., Best, D. R., Dugan, M. E. R., \& Jeremiah, L. E. (2003). Relationship of texture profile analysis and Warner-Bratzler shear force with sensory characteristics of beef rib steaks. Meat Science, 64(4), 333-339.

Campo, M. M., Sañudo, C., Panea, B., Alberti, P., \& Santolaria, P. (1999). Breed type and ageing time effects on sensory characteristics of beef strip loin steaks. Meat Science, 51(4), 383-390.

Carmen, G.-Y., \& Víctor, S.-M. (2006). Signalling mechanisms regulating lipolysis. Cellular Signalling, 18(4), 401-408.

Chambaz, A., Scheeder, M. R. L., Kreuzer, M., \& Dufey, P.-A. (2003). Meat quality of Angus, Simmental, Charolais and Limousin steers compared at the same intramuscular fat content. Meat Science, 63(4), 491-500.

Choat, W. T., Paterson, J. A., Rainey, B. M., King, M. C., Smith, G. C., Belk, K. E., \& Lipsey, R. J. (2006). The effects of cattle sex on carcass characteristics and longissimus muscle palatability. Journal of Animal Science, 84(7), 1820-1826.

Choi, Y., Davis, M. E., \& Chung, H. (2015). Effects of genetic variants in the promoter region of the bovine adiponectin (ADIPOQ) gene on marbling of Hanwoo beef cattle. Meat Science, 105, 57-62. 
Cifuni, G. F., Napolitano, F., Riviezzi, A. M., Braghieri, A., \& Girolami, A. (2004). Fatty acid profile, cholesterol content and tenderness of meat from Podolian young bulls. Meat Science, 67(2), 289-297.

Corbin, C. H., O’Quinn, T. G., Garmyn, A. J., Legako, J. F., Hunt, M. R., Dinh, T. T. N., ... Miller, M. F. (2015). Sensory evaluation of tender beef strip loin steaks of varying marbling levels and quality treatments. Meat Science, 100, 24-31.

Corcoran, M. P., Lamon-Fava, S., \& Fielding, R. A. (2007). Skeletal muscle lipid deposition and insulin resistance: effect of dietary fatty acids and exercise. The American Journal of Clinical Nutrition, 85(3), 662-677.

Curley Jr, K. O. (2006). Influence of temperament on bovine hypothalamic-pituitary-adrenal function. M.S. Thesis. Texas A\&M University: U.S.

Cuvelier, C., Clinquart, A., Hocquette, J.-F., Cabaraux, J.-F., Dufrasne, I., Istasse, L., \& Hornick, J.-L. (2006). Comparison of composition and quality traits of meat from young finishing bulls from Belgian Blue, Limousin and Aberdeen Angus breeds. Meat Science, 74(3), $522-531$.

Daley, C. A., Abbott, A., Doyle, P. S., Nader, G. A., \& Larson, S. (2010). A review of fatty acid profiles and antioxidant content in grass-fed and grain-fed beef. Nutrition Journal, 9(1), 10.

De Matos, M. (1994). Evaluating beef carcass value: a hedonic price analysis.

Delarue, J., \& Magnan, C. (2007). Free fatty acids and insulin resistance. Current Opinion in Clinical Nutrition \& Metabolic Care, 10(2), 142-148.

Du, M., Yin, J., \& Zhu, M. J. (2010). Cellular signaling pathways regulating the initial stage of adipogenesis and marbling of skeletal muscle. Meat Science, 86(1), 103-109. 
Duckett, S. K., Owens, F. N., \& Andrae, J. G. (1997). Effects of implants on performance and carcass traits of feedlot steers and heifers. In Symposium: Impact of Implants on Performance and Carcass Value of Beef Cattle (pp. 63-82).

Faucitano, L., Chouinard, P. Y., Fortin, J., Mandell, I. B., Lafreniere, C., Girard, C. L., \& Berthiaume, R. (2008). Comparison of alternative beef production systems based on forage finishing or grain-forage diets with or without growth promotants: 2. Meat quality, fatty acid composition, and overall palatability. Journal of Animal Science, 86(7), 16781689.

Ferreira, L. D.-B., Pulawa, L. K., Jensen, D. R., \& Eckel, R. H. (2001). Overexpressing human lipoprotein lipase in mouse skeletal muscle is associated with insulin resistance. Diabetes, 50(5), 1064-1068.

Gaughan, J. B., Bonner, S., Loxton, I., Mader, T. L., Lisle, A., \& Lawrence, R. (2010). Effect of shade on body temperature and performance of feedlot steers. Journal of Animal Science, 88(12), 4056-4067.

Geary, T. W., McFadin, E. L., MacNeil, M. D., Grings, E. E., Short, R. E., Funston, R. N., \& Keisler, D. H. (2003). Leptin as a predictor of carcass composition in beef cattle. Journal of Animal Science, 81(1), 1-8.

Gerken, C. L., Tatum, J. D., Morgan, J. B., \& Smith, G. C. (1995). Use of genetically identical (clone) steers to determine the effects of estrogenic and androgenic implants on beef quality and palatability characteristics. Journal of Animal Science, 73(11), 3317-3324.

Goldberg, I. J. (1996). Lipoprotein lipase and lipolysis: central roles in lipoprotein metabolism and atherogenesis. Journal of Lipid Research, 37(4), 693-707. 
Gorocica-Buenfil, M. A., Fluharty, F. L., Reynolds, C. K., \& Loerch, S. C. (2007). Effect of dietary vitamin A concentration and roasted soybean inclusion on marbling, adipose cellularity, and fatty acid composition of beef. Journal of Animal Science, 85(9), 22302242.

Hall, N. L., Buchanan, D. S., Anderson, V. L., Ilse, B. R., Carlin, K. R., \& Berg, E. P. (2011). Working chute behavior of feedlot cattle can be an indication of cattle temperament and beef carcass composition and quality. Meat Science, 89(1), 52-57.

Harper, G. S., \& Pethick, D. W. (2004). How might marbling begin? Animal Production Science, 44(7), 653-662.

Hartwig, M., Hartmann, S., \& Steinhart, H. (1997). Physiological quantities of naturally occurring steroid hormones (androgens and progestogens), precursors and metabolites in beef of differing sexual origin. Zeitschrift Für Lebensmitteluntersuchung und-Forschung A, 205(1), 5-10.

Hausman, G. J., Dodson, M. V, Ajuwon, K., Azain, M., Barnes, K. M., Guan, L. L., ... Smith, S. (2009). Board-invited review: the biology and regulation of preadipocytes and adipocytes in meat animals. Journal of Animal Science, 87(4), 1218-1246.

Herschler, R. C., Olmsted, A. W., Edwards, A. J., Hale, R. L., Montgomery, T., Preston, R. L., ... Sheldon, J. J. (1995). Production responses to various doses and ratios of estradiol benzoate and trenbolone acetate implants in steers and heifers. Journal of Animal Science, 73(10), 2873-2881.

Hocquette, J. F., Gondret, F., Baéza, E., Médale, F., Jurie, C., \& Pethick, D. W. (2010). Intramuscular fat content in meat-producing animals: development, genetic and nutritional control, and identification of putative markers. Animal, 4(02), 303-319. 
Hocquette, J.-F., Lehnert, S., Barendse, W., Cassar-Malek, I., \& Picard, B. (2007). Recent advances in cattle functional genomics and their application to beef quality.

Hood, R. L. (1982). Relationships among growth, adipose cell size, and lipid metabolism in ruminant adipose tissue. In Federation proceedings (Vol. 41, pp. 2555-2561).

Jindrichova, E., Kratochvilova, S., \& Kovar, J. (2007). Glucose administration downregulates lipoprotein lipase activity in vivo: a study using repeated intravenous fat tolerance test. Physiological Research, 56(2), 175.

Kahn, B. B. (1998). Type 2 diabetes: when insulin secretion fails to compensate for insulin resistance. Cell, 92(5), 593-596.

Kazala, E. C., Petrak, J. L., Lozeman, F. J., Mir, P. S., Laroche, A., Deng, J., \& Weselake, R. J. (2003). Hormone-sensitive lipase activity in relation to fat content of muscle in Wagyu hybrid cattle. Livestock Production Science, 79(1), 87-96.

Killinger, K. M., Calkins, C. R., Umberger, W. J., Feuz, D. M., \& Eskridge, K. M. (2004). Consumer sensory acceptance and value for beef steaks of similar tenderness, but differing in marbling level. Journal of Animal Science, 82(11), 3294-3301.

Kim, J. K., Fillmore, J. J., Chen, Y., Yu, C., Moore, I. K., Pypaert, M., ... Goldberg, I. J. (2001). Tissue-specific overexpression of lipoprotein lipase causes tissue-specific insulin resistance. Proceedings of the National Academy of Sciences, 98(13), 7522-7527.

King, D. A., Pfeiffer, C. E. S., Randel, R. D., Welsh, T. H., Oliphint, R. A., Baird, B. E., ... Savell, J. W. (2006). Influence of animal temperament and stress responsiveness on the carcass quality and beef tenderness of feedlot cattle. Meat Science, 74(3), 546-556. 
Kreikemeier, K. K., Unruh, J. A., \& Eck, T. P. (1998). Factors affecting the occurrence of darkcutting beef and selected carcass traits in finished beef cattle. Journal of Animal Science, 76(2), 388-395.

Leheska, J. M., Thompson, L. D., Howe, J. C., Hentges, E., Boyce, J., Brooks, J. C., ... Miller, M. F. (2008). Effects of conventional and grass-feeding systems on the nutrient composition of beef. Journal of Animal Science, 86(12), 3575-3585.

Mader, T. L. (2000). Growth Implants for heifers. Nebraska Beef Cattle Reports, 378.

Mader, T. L., Dahlquist, J. M., Hahn, G. L., \& Gaughan, J. B. (1999). Shade and wind barrier effects on summertime feedlot cattle performance. Journal of Animal Science, 77(8), $2065-2072$.

Mader, T. L., \& Davis, M. S. (2004). Effect of management strategies on reducing heat stress of feedlot cattle: feed and water intake. Journal of Animal Science, 82(10), 3077-3087.

Matsuzaki, M., Takizawa, S., \& Ogawa, M. (1997). Plasma insulin, metabolite concentrations, and carcass characteristics of Japanese Black, Japanese Brown, and Holstein steers. Journal of Animal Science, 75(12), 3287-3293.

Miller, M. (2007). Dark, firm and dry beef. National Cattlemen's Beef Association, Centennial, $\mathrm{CO}$.

Mir, P. S., Mir, Z., Kuber, P. S., Gaskins, C. T., Martin, E. L., Dodson, M. V, ... Wood, A. J. (2002). Growth, carcass characteristics, muscle conjugated linoleic acid (CLA) content, and response to intravenous glucose challenge in high percentage Wagyu, Wagyu $\times$ Limousin, and Limousin steers fed sunflower oil-containing diets. Journal of Animal Science, 80(11), 2996-3004. 
Mir, P. S., Schwartzkopf-Genswein, K. S., Entz, T., Klein, K. K., Okine, E., \& Dodson, M. V. (2008). Effect of a short duration feed withdrawal followed by full feeding on marbling fat in beef carcasses. Livestock Science, 116(1), 22-29.

Mitlöhner, F. M., Galyean, M. L., \& McGlone, J. J. (2002). Shade effects on performance, carcass traits, physiology, and behavior of heat-stressed feedlot heifers. Journal of Animal Science, 80(8), 2043-2050.

Moore, M. C., Gray, G. D., Hale, D. S., Kerth, C. R., Griffin, D. B., Savell, J. W., .. Tatum, J. D. (2012). National Beef Quality Audit-2011: In-plant survey of targeted carcass characteristics related to quality, quantity, value, and marketing of fed steers and heifers. Journal of Animal Science, 90(13), 5143-5151.

Nichols, W. T., Galyean, M. L., Thomson, D. U., \& Hutcheson, J. P. (2002). Review: effects of steroid implants on the tenderness of beef. The Professional Animal Scientist, 18(3), $202-210$.

Nordlie, R. C., Foster, J. D., \& Lange, A. J. (1999). Regulation of glucose production by the liver. Annual Review of Nutrition, 19(1), 379-406.

Park, G. B., Moon, S. S., Ko, Y. D., Ha, J. K., Lee, J. G., Chang, H. H., \& Joo, S. T. (2002). Influence of slaughter weight and sex on yield and quality grades of Hanwoo (Korean native cattle) carcasses. Journal of Animal Science, 80(1), 129-136.

Pickworth, C. L., Loerch, S. C., \& Fluharty, F. L. (2012). Restriction of vitamin A and D in beef cattle finishing diets on feedlot performance and adipose accretion. Journal of Animal Science, 90(6), 1866-1878. 
Platter, W. J., Tatum, J. D., Belk, K. E., Koontz, S. R., Chapman, P. L., \& Smith, G. C. (2005). Effects of marbling and shear force on consumers' willingness to pay for beef strip loin steaks. Journal of Animal Science, 83(4), 890-899.

Priolo, A., Micol, D., \& Agabriel, J. (2001). Effects of grass feeding systems on ruminant meat colour and flavour. A review. Animal Research, 50(3), 185-200.

Pyatt, N. A., \& Berger, L. L. (2005). Review: potential effects of vitamins a and D on marbling deposition in beef cattle. The Professional Animal Scientist, 21(3), 174-181.

Shanik, M. H., Xu, Y., Škrha, J., Dankner, R., Zick, Y., \& Roth, J. (2008). Insulin Resistance and Hyperinsulinemia Is hyperinsulinemia the cart or the horse? Diabetes Care, 31(Supplement 2), S262-S268.

Shingu, H., Hodate, K., Kushibiki, S., Ueda, Y., Watanabe, A., Shinoda, M., \& Matsumoto, M. (2001). Profiles of growth hormone and insulin secretion, and glucose response to insulin in growing Japanese Black heifers (beef type): comparison with Holstein heifers (dairy type). Comparative Biochemistry and Physiology Part C: Toxicology \& Pharmacology, 130(2), 259-270.

Smith, K. R., Duckett, S. K., Azain, M. J., Sonon, R. N., \& Pringle, T. D. (2007). The effect of anabolic implants on intramuscular lipid deposition in finished beef cattle. Journal of Animal Science, 85(2), 430-440.

Trenkle, A., \& Topel, D. G. (1978). Relationship of some endocrine measurements to growth and carcass composition of cattle. Journal of Animal Science, 46(6), 1604-1609.

Umberger, W. J., Feuz, D. M., Calkins, C. R., \& Killinger, K. M. (2000). The value of beef flavor: Consumer willingness-to-pay for marbling in beef steaks. Western Agric. Econ. Assoc. Annu. Mtg. Vancouver, BC, Canada. 
USDA. (1997). Official United States Standards for grades of carcass beef.

USDA. (2006). Instrument Grading Systems for Beef Carcasses.

Voshol, P. J., Jong, M. C., Dahlmans, V. E. H., Kratky, D., Levak-Frank, S., Zechner, R., ... Havekes, L. M. (2001). In muscle-specific lipoprotein lipase-- overexpressing mice, muscle triglyceride content is increased without inhibition of insulin-stimulated wholebody and muscle-specific glucose uptake. Diabetes, 50(11), 2585-2590.

Wegner, J., Huff, P., Xie, C. P., Schneider, F., Teuscher, F., Mir, P. S., ... Ender, K. (2001). Relationship of plasma leptin concentration to intramuscular fat content in beef from crossbred Wagyu cattle. Canadian Journal of Animal Science, 81(4), 451-457.

Wellnitz, K. 2014. Body weight and adiposity changes of obese gilts provided ad libitum ground beef versus high carbohydrate diets. M.S. Thesis. North Dakota State University: U.S.

West, J. W. (2003). Effects of heat-stress on production in dairy cattle. Journal of Dairy Science, 86(6), 2131-2144.

Wheeler, T. L., Cundiff, L. V, Shackelford, S. D., \& Koohmaraie, M. (2005). Characterization of biological types of cattle (Cycle VII): Carcass, yield, and longissimus palatability traits. Journal of Animal Science, 83(1), 196-207.

Wong, R. H. F., \& Sul, H. S. (2010). Insulin signaling in fatty acid and fat synthesis: a transcriptional perspective. Current Opinion in Pharmacology, 10(6), 684-691.

Wood, J. D., Enser, M., Fisher, A. V, Nute, G. R., Sheard, P. R., Richardson, R. I., ... Whittington, F. M. (2008). Fat deposition, fatty acid composition and meat quality: A review. Meat Science, 78(4), 343-358.

Xie, C., Albrecht, E., Wegner, J., Brockmann, G. A., Kazala, C., Weselake, R. J., \& Ender, K. (1999). Leptin, a palatability molecule? - a review. Arch. Tierz, 42, 191-199. 
Yang, X. J., Albrecht, E., Ender, K., Zhao, R. Q., \& Wegner, J. (2006). Computer image analysis of intramuscular adipocytes and marbling in the longissimus muscle of cattle. Journal of Animal Science, 84(12), 3251-3258.

Zheng, C.-M., Ma, W.-Y., Wu, C.-C., \& Lu, K.-C. (2012). Glycated albumin in diabetic patients with chronic kidney disease. Clinica Chimica Acta, 413(19), 1555-1561.

Zilg, H., Schneider, H., \& Seiler, F. R. (1979). Molecular aspects of albumin functions: indications for its use in plasma substitution. Developments in Biological Standardization, 48, 31-42. 


\title{
CHAPTER II. EVALUATION OF GLYCATED ALBUMIN AS A METABOLIC MARKER FOR MARBLING IN COMMERCIAL FEEDER CATTLE
}

\begin{abstract}
The objective of this study was to determine if glycated albumin could serve as a metabolic marker associated with marbling in beef cattle. This project utilized 113 crossbred steers that were consigned to the NDSU Beef Cattle Research Complex for a separate feeding trial. Steers $(862 \pm 6.17 \mathrm{lbs})$ were randomly assigned to a $2 \times 2 \times 2$ factorial arrangement of treatments ( $\mathrm{n}=14$ or 15 per treatment) to determine the effects of conventional (CONV) or natural (NAT) feeding strategies (using monensin, tylosin, and trenbolone acetate/estradiol vs. none), and direct fed microbial supplementations (with or without), and grain adaptation length (14 vs. 28 day). Diets consisted of corn, dried corn distillers grains with solubles, and 10\% forage (hay and corn silage). Blood samples were collected on days 28, 56, 84, 112, and 140 to determine serum concentrations of glucose (T-GLU) and insulin (T-INSU). Additionally, on day 140 prior to slaughter, separate blood samples were collected to evaluate total serum protein (TSP), total serum albumin (T-SA), total serum glycated albumin (T-GA), and percent of T-GA (PGA). After 140 days on feed, all steers were delivered as one group to a commercial packing facility. Hot carcass weight was measured on the day of slaughter and carcass measurements (subcutaneous fat thickness adjacent at the $12^{\text {th }}$ rib [FD12], $12^{\text {th }}$ rib ribeye area [REA], marbling score, and kidney, pelvic, and heart fat percentage $[\mathrm{KPH}]$ ) were measured following a $24 \mathrm{~h}$ chill. Total serum protein and T-SA were not influenced by treatment relative to marbling score and feeding strategy and did not correlate with marbling score. There was treatment difference for TGA and P-GA with CONV possessing a greater concentration of T-GA and P-GA (115.02 vs. $74.43 \mu \mathrm{mol} / \mathrm{L}, \mathrm{P}=0.001 ; 38.88$ vs. $16.3 \%, \mathrm{P}=0.001$, respectively). Neither T-GA nor P-GA
\end{abstract}


correlated with marbling score, however, both had a significant negative correlation with KPH and FD12. Carcasses from NAT fed steers had greater T-GLU concentrations than CONV (115.86 vs. $107.21 \mathrm{mg} / \mathrm{dL}$, respectively; $\mathrm{P}=0.02$ ). Likewise, steers possessing a slight degree of marbling had the highest T-GLU (compared to other marbling categories; $\mathrm{P}=<0.0001$ ). The average of T-INSU for modest and moderate marbling scores were greater than small (33.18 and 36.59 vs. $26.84 \mu \mathrm{U} / \mathrm{mL}$, respectively; $\mathrm{P}=0.01$ ), however, all were similar to slight and slightly abundant. Glycated albumin was found to be negatively correlated with the fat depots KPH and FD12 but not associated with marbling score.

\section{Introduction}

Marbling is a term used in the beef industry referring to the flecks of intramuscular fat (IMF) located between the muscle fiber bundles that begin to develop during postnatal growth. Fat accumulation is mainly due to adipocyte hypertrophy (Hood, 1982). Marbling is one of the most important meat quality characteristics because it positively correlates with and influences flavor, tenderness, and juiciness, has a positive correlation with the USDA quality grade (a greater grade indicates more profit to producer) and marbled meats are in high demand by retail and foodservice customers (Harper et al., 2004; Killinger et al., 2004). Therefore, there has been a great deal of scientific interest to uncover the complex interaction of genetics and environment relative to marbling deposition.

Our previous research (Berg, unpublished data) had suggested that the longer cattle are fed a high concentrate (high carbohydrate) diet; the liver and muscle cells become saturated with energy as glucose/glycogen. The liver and muscle are no longer a viable means of disposal for circulating blood glucose, however, the adipocytes remain viable. Therefore, the excess glucose is converted to fatty acids in the liver, circulated as triglycerides, and deposited in adipocyte via 
the insulin-mediated pathway (Carmen et al., 2006). The applied research component of this process is to identify physiologically when the shift in tissue-specific insulin resistance occurs in order to maximize marbling in an effort to achieve USDA Choice or higher while balancing against the accumulation of external (subcutaneous) fat which could lead to discounts associated with USDA Yield Grade 4 or 5. We had originally hypothesized that if blood glucose remains elevated for a prolonged period of time (hyperglycemia), it has negative consequences on other blood molecules such as albumin. Albumin is one of the most predominant proteins in the blood plasma (Choi et al, 2004). With chronic hyperglycemia, a non-enzymatic glycation of albumin may occur (Zheng, et al, 2012). Furthermore, glycated albumin (GA) is currently used as a marker to screen for pre-diabetes and metabolic syndrome (Koga, et al, 2010). Therefore, the objective of this study was to determine if glycated albumin can serve as a metabolic marker associated with marbling in beef cattle.

\section{Materials and Methods}

This study was conducted at North Dakota State University Animal Sciences Department. All animal procedures were approved by the Institutional Animal Care and Use Committee (IACUC).

\section{Animals}

This project utilized 113 crossbred steers that were consigned to the NDSU Beef Research Complex to a separate feeding trial. Steers $(391 \pm 2.8 \mathrm{~kg})$ were assigned randomly to a $2 \times 2 \times 2$ factorial arrangement of treatments ( $n=14$ or 15 per treatment) to determine the effects of conventional (CONV) vs. natural (NAT) feeding strategies (using monensin, tylosin, and trenbolone acetate/estradiol vs. none), grain adaptation length (14 vs. $28 \mathrm{~d}$ ), and direct fed microbial supplementations (with or without; Table 2.1). 
Table 2.1. Treatment design.

\begin{tabular}{lccc}
\hline Treatment & Adaptation length & Feeding strategy & Microbial supplementations \\
\hline 1 & 28 day & Conventional & Without \\
2 & 28 day & Conventional & With \\
3 & 14 day & Conventional & Without \\
4 & 14 day & Conventional & With \\
5 & 28 day & Natural & Without \\
6 & 28 day & Natural & With \\
7 & 14 day & Natural & Without \\
8 & 14 day & Natural & With \\
\hline
\end{tabular}

Diets consisted of corn, dried corn distillers grains with solubles, and 10\% forage (hay and corn silage; Table 2.2). After 140 days on feed, all steers were delivered to market as one group and slaughtered at a commercial packing facility. Hot carcass weight was measured on the day of slaughter and carcass measurements were measured following a 24h chill. Measurements collected were subcutaneous fat thickness at the $12^{\text {th }}$ rib, $12^{\text {th }}$ rib ribeye area, marbling score, and kidney, pelvic, and heart fat percentage.

\section{Blood Collection}

Blood samples were collected on days 28, 56, 84, 112, and 140 and analyzed for glucose and insulin. On day 140, prior to slaughter, separate blood samples were collected to evaluate total serum protein (T-SP), total serum albumin (T-SA), and total serum glycated albumin (TGA). Grain adaptation duration and microbial supplementations had no influence on serum concentration of blood proteins and will not be discussed. Moreover, there was a variation in serum color between the collected serum samples, which indicates varying degrees of hemolysis and sample contamination with free hemoglobin. Some of the serum samples were reddish, which interfered with the measurement of light absorbance via utilizing the spectrophotometer. In addition, some of the serum samples had great content of lipids that made them turbid, and which also interfered with the measurement of light absorbance. Therefore, some of these serum samples were eliminated from this study due to the great light absorbance recorded. 


\section{Bovine Serum Albumin Measurement}

Bovine serum albumin (BSA) solution was utilized as a calibrator for the measurement of total serum protein and albumin. BSA was purchased from Sigma (Sigma-Aldrich, St. Louis, MO).

Table 2.2. Diet composition. ${ }^{1}$

\begin{tabular}{|c|c|c|}
\hline Ingredient, \% & Conventional & Natural \\
\hline Dry-rolled corn & 71.00 & 71.00 \\
\hline Corn dried distillers grains plus solubles & 10.00 & 10.00 \\
\hline Corn silage & 9.00 & 9.00 \\
\hline Grass legume hay & 5.00 & 5.00 \\
\hline Fine ground corn & 2.02 & 2.05 \\
\hline Limestone & 1.50 & 1.50 \\
\hline Urea & 1.00 & 1.00 \\
\hline Salt & 0.20 & 0.20 \\
\hline Concentrated separator byproduct & 0.15 & 0.15 \\
\hline Trace mineral premix ${ }^{2}$ & 0.05 & 0.05 \\
\hline Vitamin premix ${ }^{3}$ & 0.05 & 0.05 \\
\hline Rumensin premix ${ }^{4}$ & 0.02 & 0 \\
\hline Tylan premix ${ }^{5}$ & 0.01 & 0 \\
\hline
\end{tabular}

${ }^{\mathrm{T}}$ For direct fed microbial treatments, 1 ounce per day of microbial supplementations per head was added to the total mixed diet for the first 14 days. From day 15 until the end of the trial, 1/2 ounce of microbial supplementations per head was added to the total mixed diet.

${ }^{2}$ Contained $3.62 \% \mathrm{Ca}, 2.56 \% \mathrm{Cu}, 16 \% \mathrm{Zn}, 6.5 \% \mathrm{Fe}, 4.0 \% \mathrm{Mn}, 1,050 \mathrm{mg} / \mathrm{kg} \mathrm{I}$, and $250 \mathrm{mg} / \mathrm{kg}$ Co.

${ }^{3}$ Contained 48,510 kIU/kg vitamin A and 4,630.5 kIU/kg vitamin D.

${ }^{4}$ Contained $176.4 \mathrm{~g}$ monensin $/ \mathrm{kg}$ premix.

${ }^{5}$ Contained $88.2 \mathrm{~g}$ tylosin/kg premix.

\section{Total Serum Protein Measurement}

Total serum protein was measured by the biuret assay described by Doumas (1975).

Briefly, $0.15 \mathrm{~g}$ of copper sulfate and $0.6 \mathrm{~g}$ sodium potassium tartrate were dissolved in $30 \mathrm{ml}$ of distilled water $\left(\mathrm{d}-\mathrm{H}_{2} \mathrm{O}\right)$ and $5 \mathrm{ml}$ of $5 \mathrm{M}$ sodium hydroxide $(\mathrm{NaOH})$ was added to the solution. Then, the solution volume was brought to $50 \mathrm{ml}$ with $\mathrm{d}-\mathrm{H}_{2} \mathrm{O}$. Samples were $10 \mathrm{X}$ diluted in d$\mathrm{H}_{2} \mathrm{O}$. A 96 well microplate was utilized for the measurement of total serum protein. A $40 \mu \mathrm{l}$ portion of each diluted sample was pipetted to each well of the microplate and $200 \mu$ of the 
biuret reagent was added to the diluted sample and mixed. The light absorbance was then measured at $570 \mathrm{~nm}$ on a microplate spectrophotometer to quantify total serum protein $(\mathrm{g} / \mathrm{L})$.

\section{Albumin Measurement}

The measurement of T-SA was done by the bromocresol green (BCG) assay as described by Koupparis et al. (1985). Succinate buffer was prepared by dissolving $4.8 \mathrm{~g}$ of succinic acid in $200 \mathrm{ml}$ of $\mathrm{d}-\mathrm{H}_{2} \mathrm{O}$. The $\mathrm{pH}$ was then adjusted to 4.0 with $0.1 \mathrm{M} \mathrm{NaOH}$. Next, $168 \mathrm{mg}$ of BCG were dissolved in $10 \mathrm{ml}$ of $0.1 \mathrm{M} \mathrm{NaOH}$, the solution volume was brought to $200 \mathrm{ml}$ with $\mathrm{d}-\mathrm{H}_{2} \mathrm{O}$, $50 \mathrm{ml}$ of the BCG solution was diluted with $150 \mathrm{ml}$ of succinate buffer, and $0.8 \mathrm{ml}$ of $30 \%$ Brij35 was added to the solution. The $\mathrm{pH}$ of the final BCG solution was adjusted to 4.2 with $0.1 \mathrm{M}$ $\mathrm{NaOH}$. Samples were 10X diluted in $\mathrm{d}-\mathrm{H}_{2} \mathrm{O}$. A 96 well microplate was utilized for the measurement of albumin. Forty $\mu 1$ of each diluted sample was pipetted in to each well of the microplate and $200 \mu 1$ of the BCG reagent was added to the diluted sample and mixed. The light absorbance was then measured at $630 \mathrm{~nm}$ on a microplate spectrophotometer to quantify total serum albumin $(\mathrm{g} / \mathrm{L})$.

\section{Glycated Albumin Measurement}

The reagents utilized for the measurement of T-GA were purchased from Diazyme Laboratories (Diazyme Laboratories, Poway, CA). The assay procedure was included in the package and the procedures are briefly described here. After thawing the blood samples, $40 \mu \mathrm{l}$ from each samples were pipetted in to each well of a 96 well microplate. Two hundred $\mu 1$ of reagent 1 was added to each sample, and they were incubated at $37^{\circ} \mathrm{C}$ for 60 minutes. After 60 minutes of incubation and before adding reagent 2, light absorbance (Abs 1) was recorded at 546 $\mathrm{nm}$ on a microplate spectrophotometer. Fifty $\mu 1$ of reagent 2 was added and mixed with the sample and reagent 1 and then incubated at $37^{\circ} \mathrm{C}$ for 30 minutes. After 30 minutes incubation, 
light absorbance (Abs 2) was again recorded at $546 \mathrm{~nm}$. The calculation of GA and \%GA were calculated as Abidin et al. (2013) described. The change in absorbance $(\Delta \mathrm{A})$ was calculated as followed;

$$
\Delta A=(\text { Abs } 2)-[(A b s 1) \times 240 \text { (volume before reagent } 2 \text { addition) } / 290 \text { (total valum) }]
$$

After obtaining $\Delta \mathrm{A}$, a calibration curve was plotted to obtain specimen GA values. Percent of GA (P-GA) was calculated as followed

$$
P-G A=[(G A(\mu \mathrm{mol} / \mathrm{l}) \times 0.182+1.97) / \text { total albumin }(g / d l)]
$$

\section{Statistical Analysis}

Differences in T-SP, T-SA, T-GA, and P-GA for each degree of marbling category were analyzed using the MIXED procedure of SAS (SAS Institute, Cary, NC; version 9.4) and generalized least square means as repeated measures with the fixed effects of treatment, day, and marbling. The correlation between and across carcass measurements, serum proteins, glycated proteins and degree of marbling were analyzed using the CORR procedure of SAS.

\section{Results and Discussion}

\section{Total Serum Protein}

Table 2.3 reports the means and standard deviation of carcass composition and blood metabolites. There were no treatment differences seen for T-SP between feeding strategies (Table 2.4), microbial supplementations, and grain adaptation length (data not presented). Moreover, there was no correlation between T-SP and marbling score (Table 2.5). There were no treatment differences seen for least squares means for T-SP across USDA official marbling score (Table 2.6).

Total serum protein was not correlated with marbling (Table 2.5). However, T-SP was associated with total serum albumin $(\mathrm{r}=0.77 ; \mathrm{P}=0.001$; T-SA; Table 2.5$)$ because T-SA is the 
most abundant protein in blood (Choi et al, 2004). That said, lipoproteins such as high-density lipoprotein (HDL) and very low-density lipoprotein (VLDL) are also fractions of T-SP and VLDL has been associated with IMF deposition because it transfers triglycerides (TG) from liver to adipocytes and muscle tissues (Muñoz et al., 2012; Kaneko et al., 2008). A study by Muñoz et al. (2012) evaluated the relationship between blood lipid indicators and fat content in Duroc pigs. The results showed a positive correlation between IMF and circulating T-SP, indicating that TSP is a good biomarker for early estimation of fatness. Total serum protein in the current study were similar to the values in Japanese Black beef steers and Shorthorn heifers $(76.2,74.6$, vs. $71.2 \mathrm{~g} / \mathrm{L}$, respectively) reported by Kozo et al. (1997) and Doornenbal et al. (1988).

Table 2.3. Mean, standard deviation, and range for carcass parameters and blood metabolites collected after 140 days on feed.

\begin{tabular}{lccccc}
\hline Variable & N & Mean & Std Dev & Minimum & Maximum \\
\hline Final live weight, kg & 111 & 606 & 97.39 & 499 & 706 \\
Hot carcass weight, kg & 111 & 364 & 62.18 & 286 & 425 \\
Marbling Score $^{1}$ & 111 & 488 & 92.42 & 330 & 720 \\
Yield grade & 111 & 3.41 & 0.54 & 1.89 & 4.55 \\
Kidney, Pelvic, \& Heart fat, \% & 111 & 1.87 & 0.21 & 1.32 & 2.57 \\
$12^{\text {th }}$ Rib Ribeye area, cm & 111 & 74.20 & 7.00 & 58.45 & 98.00 \\
$12^{\text {th }}$ Rib Fat Depth, cm & 111 & 1.20 & 0.33 & 0.43 & 2.00 \\
Total Serum Protein, g/L & 108 & 76.2 & 8.48 & 45.4 & 93.6 \\
Total Albumin, g/L & 108 & 41.0 & 7.12 & 16.2 & 55.0 \\
Total Glycated Albumin, $\mu$ mol/L & 109 & 95.3 & 65.7 & 2.92 & 343 \\
Glycated Albumin, \% & 106 & 20.3 & 12.1 & 3.48 & 65.4 \\
\hline${ }^{1}$ Marbling score; 300 = slight, 400 & small, 500=modest, $600=$ Moderate, $700=$ slightly \\
abundant & \multicolumn{5}{c}{}
\end{tabular}

\section{Total Serum Albumin}

There were no treatment differences associated with T-SA between feeding strategies (Table 2.4), microbial supplementations, and grain adaptation length (data not presented). Moreover, T-SA was not significantly correlated with marbling score (Table 2.5) and no treatment difference was seen for least squares means for T-SA across USDA marbling scores (Table 2.6). 
Total serum albumin was not correlated with marbling in the present study, however, albumin is a transporter molecule which can transport metabolic products, regulatory mediators, nutrients, and proteins from one tissue to another (Zilg et al., 1979). Moreover, because fatty acids are not soluble in blood, albumin functions as a transporter for fatty acids from extracellular fluids to parenchymal cells such as myocytes (van der Vusse, 2009). Total serum albumin can be utilized as a marker for long-term protein intake. Jones et al. (1990) showed that a decline in albumin synthesis was associated with dietary protein deficiency. Our T-SA values did not differ across treatments likely because protein intake was constant throughout the study. Our values of T-SA in the current study were similar to the values of Aberdeen Angus and Criollo Argentino beef heifers (41.0, 44.0, vs. $42.0 \mathrm{~g} / \mathrm{L}$, respectively), which were reported by Grünwaldt et al. (2005).

Table 2.4. Influence of feeding strategy on carcass parameters and blood metabolites collected after 140 days on feed.

\begin{tabular}{|c|c|c|c|c|}
\hline Ingredient & Conventional & Natural & SEM $^{1}$ & P-values \\
\hline Final live weight, $\mathrm{kg}$ & 620 & 593 & \pm 17.65 & 0.0009 \\
\hline Hot carcass weight, $\mathrm{kg}$ & 374 & 353 & \pm 10.93 & $<.0001$ \\
\hline Dry matter intake, $\mathrm{kg} / \mathrm{d}$ & 11.37 & 11.21 & \pm 0.62 & 0.48 \\
\hline Average daily gain ${ }^{2}, \mathrm{~kg}$ & 1.62 & 1.44 & \pm 0.07 & $<.0001$ \\
\hline Marbling Score ${ }^{3}$ & 470 & 506 & \pm 17.28 & 0.03 \\
\hline Yield grade & 3.44 & 3.36 & \pm 0.10 & 0.39 \\
\hline Kidney, Pelvic, \& Heart fat, \% & 1.81 & 1.92 & \pm 0.03 & 0.002 \\
\hline $12^{\text {th }}$ Rib Ribeye area, $\mathrm{cm}^{2}$ & 75.43 & 73.08 & \pm 0.36 & 0.07 \\
\hline $12^{\text {th }}$ Rib Fat Depth, $\mathrm{cm}$ & 1.21 & 1.16 & \pm 0.02 & 0.44 \\
\hline Total Serum Protein, g/L & 76.25 & 76.22 & \pm 1.64 & 0.98 \\
\hline Total Albumin, g/L & 41.70 & 40.19 & \pm 1.36 & 0.27 \\
\hline Total Glycated Albumin, $\mu \mathrm{mol} / \mathrm{L}$ & 115.02 & 74.35 & \pm 12.01 & 0.001 \\
\hline Glycated Albumin, \% & 23.88 & 16.22 & \pm 2.24 & 0.0009 \\
\hline
\end{tabular}

${ }^{1}$ Standard error.

${ }^{2}$ Calculated by dividing BW change by 140 days on feed.

${ }^{3}$ Marbling score; $300=$ slight, $400=$ small, $500=$ modest, $600=$ Moderate, $700=$ slightly abundant. 


\section{Total Serum Glycated Albumin}

There were no treatment differences associated with T-GA or P-GA between microbial supplementations and grain adaptation length (data not presented). However, the CONV feeding strategy revealed greater serum concentration of T-GA (115.02 vs. $74.35 \mu \mathrm{mol} / \mathrm{L} ; \mathrm{P}=0.001$; Table 2.4) and P-GA (23.88 vs. $16.22 \% ; \mathrm{P}=0.0009$; Table 2.4$)$ than NAT. This said, there was no correlation between T-GA and P-GA and marbling score (Table 2.5). However, there were significant correlations between T-GA $(\mathrm{r}=-0.33 ; \mathrm{P}=0.0004)$ and P-GA $(\mathrm{r}=-0.32 ; \mathrm{P}=0.006)$ with carcass KPH and T-GA $(r=-0.22 ; \mathrm{P}=0.01)$ and P-GA $(r=-0.21 ; \mathrm{P}=0.02)$ with FD12 (Table 2.5). There were no differences seen in least squares means for T-GA and P-GA across USDA marbling score (Table 2.6).

Table 2.5. Pearson correlation coefficients for Marb, KPH, REA, FD12, T-SP, T-SA, T-GA, and P-GA.

\begin{tabular}{|c|c|c|c|c|c|c|c|}
\hline & KPH & REA & FD12 & T-SP & T-SA & T-GA & P-GA $^{8}$ \\
\hline Marb $^{1}$ & $0.366^{*}$ & -0.100 & $0.362 *$ & -0.058 & -0.060 & -0.12 & -0.11 \\
\hline $\mathbf{K P H}^{2}$ & & $-0.22^{\dagger}$ & $0.54 *$ & -0.08 & -0.04 & $-0.33^{*}$ & $-0.32 *$ \\
\hline REA $^{3}$ & & & -0.08 & -0.01 & -0.05 & 0.11 & 0.1 \\
\hline FD12 ${ }^{4}$ & & & & -0.04 & 0.002 & $-0.22^{\dagger}$ & $-0.21^{\dagger}$ \\
\hline T-SP ${ }^{5}$ & & & & & $0.77 *$ & -0.03 & -0.03 \\
\hline$T_{-S A^{6}}$ & & & & & & 0.05 & 0.05 \\
\hline T-GA ${ }^{7}$ & & & & & & & $1 *$ \\
\hline $\begin{array}{l}* \mathrm{P}<0.0 \\
{ }^{1} \text { Marblis } \\
{ }^{2} \text { Kidney } \\
{ }^{3} 12^{\text {th }} \mathrm{rib} \\
{ }^{4} 12^{\text {th }} \mathrm{Ril} \\
{ }^{5} \text { Total s } \\
{ }^{6} \text { Total s } \\
{ }^{7} \text { Total s } \\
{ }^{8} \text { Glycate }\end{array}$ & $\begin{array}{l}<0.01 \text {, } \\
\text { \& hear } \\
\text { area. } \\
\text { pth. } \\
\text { otein. } \\
\text { oumin. } \\
\text { ycated a } \\
\text { nin, perc }\end{array}$ & $\begin{array}{l}<<0.10 \\
\text { percent }\end{array}$ & 0.05 & & & & \\
\hline
\end{tabular}

As discussed previously, glycation of albumin may occur with hyperglycemia (Zheng, et al, 2012). Glycated endproducts such as T-GA have been used as a diagnostic tool for risk factors associated with pre-diabetes or metabolic syndrome and body composition (Koga, et al, 
2010). Our hypothesis suggested that prolonged hyperglycemia could lead to excusive fat deposition, which could lead to obesity and, because T-GA has been linked to and used as a diabetic indicator, it has potential as a physiological indicator for marbling. We were not able to link T-GA with marbling. However, there was a significantly negative correlation between T-GA and other fat depots; KPH and FD12. This negative correlation is interesting and unexpected because both KPH and FD12 have a positive significant correlation with marbling score.

Table 2.6. Least squares means (standard error) for blood metabolites across USDA marbling score.

$$
\text { USDA Degree of Marbling }
$$

\begin{tabular}{|c|c|c|c|c|c|c|}
\hline & \multicolumn{6}{|c|}{ USDA Degree of Marbling } \\
\hline & $\begin{array}{l}\text { Slight } \\
(\mathrm{n}=18)\end{array}$ & $\begin{array}{c}\text { Small } \\
(\mathrm{n}=48)\end{array}$ & $\begin{array}{l}\text { Modest } \\
(\mathrm{n}=30)\end{array}$ & $\begin{array}{l}\text { Moderate } \\
(\mathrm{n}=10)\end{array}$ & $\begin{array}{c}\text { Slightly } \\
\text { Abundant } \\
(\mathrm{n}=4)\end{array}$ & P-values \\
\hline $\mathrm{T}^{\mathrm{INSU}}{ }^{1}, \mu \mathrm{U} / \mathrm{mL}$ & $\begin{array}{c}30.1^{\mathrm{b}} \\
( \pm 2.27)\end{array}$ & $\begin{array}{c}26.9^{\mathrm{b}} \\
( \pm 1.41)\end{array}$ & $\begin{array}{c}32.2^{\mathrm{a}, \mathrm{b}} \\
( \pm 1.74)\end{array}$ & $\begin{array}{c}38.5^{\mathrm{a}} \\
( \pm 3.14)\end{array}$ & $\begin{array}{c}34.4^{\mathrm{a}, \mathrm{b}} \\
( \pm 4.88)\end{array}$ & 0.005 \\
\hline $\mathrm{T}-\mathrm{GLU}^{2}, \mathrm{mg} / \mathrm{dL}$ & $\begin{array}{c}120^{\mathrm{a}} \\
( \pm 2.14)\end{array}$ & $\begin{array}{c}110^{\mathrm{b}} \\
( \pm 1.31)\end{array}$ & $\begin{array}{c}107^{\mathrm{b}} \\
( \pm 1.65)\end{array}$ & $\begin{array}{c}106^{b^{b}} \\
( \pm 2.72)\end{array}$ & $\begin{array}{l}102^{\mathrm{b}} \\
( \pm 4.56)\end{array}$ & $<.0001$ \\
\hline $\mathrm{T}-\mathrm{SP}^{3}, \mathrm{~g} / \mathrm{L}$ & $\begin{array}{c}74.6 \\
( \pm 2.06)\end{array}$ & $\begin{array}{c}77.5 \\
( \pm 1.23)\end{array}$ & $\begin{array}{c}76.5 \\
( \pm 1.58)\end{array}$ & $\begin{array}{c}73.3 \\
( \pm 2.69)\end{array}$ & $\begin{array}{c}73.7 \\
( \pm 4.26)\end{array}$ & 0.524 \\
\hline $\mathrm{T}-\mathrm{SA}^{4}, \mathrm{~g} / \mathrm{L}$ & $\begin{array}{c}40.9 \\
( \pm 1.75)\end{array}$ & $\begin{array}{c}41.4 \\
( \pm 1.05)\end{array}$ & $\begin{array}{c}41.2 \\
( \pm 1.34)\end{array}$ & $\begin{array}{c}38.8 \\
( \pm 2.17)\end{array}$ & $\begin{array}{c}39.8 \\
( \pm 3.60)\end{array}$ & 0.855 \\
\hline $\mathrm{T}-\mathrm{GA}^{5}, \mu \mathrm{mol} / \mathrm{L}$ & $\begin{array}{c}127 \\
( \pm 15.3)\end{array}$ & $\begin{array}{c}87.9 \\
( \pm 9.40)\end{array}$ & $\begin{array}{c}89.8 \\
( \pm 11.9)\end{array}$ & $\begin{array}{c}80.7 \\
( \pm 21.7)\end{array}$ & $\begin{array}{c}110 \\
( \pm 32.5)\end{array}$ & 0.211 \\
\hline $\mathrm{P}-\mathrm{GA}^{6}, \%$ & $\begin{array}{c}26.1 \\
( \pm 2.91)\end{array}$ & $\begin{array}{c}18.9 \\
( \pm 1.75)\end{array}$ & $\begin{array}{c}19.4 \\
( \pm 2.23)\end{array}$ & $\begin{array}{c}17.6 \\
( \pm 4.00)\end{array}$ & $\begin{array}{c}22.9 \\
( \pm 6.00)\end{array}$ & 0.256 \\
\hline
\end{tabular}

${ }^{\mathrm{a}, \mathrm{b}}$ means within a row followed by the same letter are not significantly different $(\mathrm{P}>0.05)$.

${ }^{1}$ Total serum insulin.

${ }^{2}$ Total serum glucose.

${ }^{3}$ Total serum protein.

${ }^{4}$ Total serum albumin.

${ }^{5}$ Total serum glycated albumin.

${ }^{6}$ Glycated albumin, percent.

\section{Glucose Concentration}

Tables 2.7 and Figure 2.1 present the concentration of glucose in blood on days 28, 56, 84,112 , and 140 across marbling score category. On day 28 , the glucose concentration from steers delivering carcasses that possessed a marbling score of slight was significantly greater 
(112.12 $\mathrm{mg} / \mathrm{dL} ; \mathrm{P}=0.02)$ than all other marbling scores (Table 2.7). The glucose concentration of marbling score slight, small, or slightly abundant on day 112 did not differ (137.55 vs. 126.67 vs. $109.23 \mathrm{mg} / \mathrm{dL}$, respectively; Table 2.7), however, the carcasses possessing slight marbling were greater than modest and moderate (137.55 vs. 118.72 vs. $110.44 \mathrm{mg} / \mathrm{dL}$, respectively; $\mathrm{P}=$ 0.02; Table 2.7) and marbling scores of small and slightly abundant were similar to modest and moderate (126.67 vs. 109.23 vs. 118.72 vs. 110.44 mg/dL, respectively; Table 2.7). On days 56, 84, and 140 glucose concentrations were similar for all marbling scores. Overall, the average glucose concentration associated with slight marbling score was greater than all marbling scores (121.8 mg/dL; $\mathrm{P}=<.0001 ;$ Table 2.7 and Figure 2.1).

Table 2.7. Glucose concentration (mg/dL) over day and marbling score.

\begin{tabular}{lcccccc}
\hline Marbling Score & $\mathbf{d 2 8}$ & $\mathbf{d 5 6}$ & $\mathbf{d 8 4}$ & $\mathbf{d 1 1 2}$ & $\mathbf{d 1 4 0}$ & Average \\
\hline Slight & $112.12^{\mathrm{a}}$ & 117.57 & 121.87 & $137.55^{\mathrm{a}}$ & 119.75 & $121.8^{\mathrm{a}}$ \\
& $( \pm 3.96)$ & $( \pm 3.98)$ & $( \pm 4.59)$ & $( \pm 5.68)$ & $( \pm 5.29)$ & $( \pm 3.61)$ \\
Small & $101.47^{\mathrm{b}}$ & 109.29 & 110.91 & $125.67^{\mathrm{a}, \mathrm{b}}$ & 111.58 & $111.77^{\mathrm{b}}$ \\
& $( \pm 2.48)$ & $( \pm 2.39)$ & $( \pm 2.84)$ & $( \pm 3.55)$ & $( \pm 3.24)$ & $( \pm 3.2)$ \\
Modest & $96.13^{\mathrm{b}}$ & 104.9 & 109.45 & $118.72^{\mathrm{b}}$ & 112.48 & $\left(108.34^{\mathrm{b}}\right.$ \\
& $( \pm 3.07)$ & $( \pm 3.04)$ & $( \pm 3.55)$ & $( \pm 4.4)$ & $( \pm 4.1)$ & $( \pm 3.35)$ \\
Moderate & $96.36^{\mathrm{b}}$ & 105.25 & 105.58 & $110.44^{\mathrm{b}}$ & 116.99 & $\left(107.08^{\mathrm{b}}\right.$ \\
& $( \pm 5.07)$ & $( \pm 4.94)$ & $( \pm 5.87)$ & $( \pm 7.6)$ & $( \pm 6.77)$ & $( \pm 4.00)$ \\
Slightly Ab. & $97.93^{\mathrm{b}}$ & 102.56 & 102.28 & $109.23^{\mathrm{a}, \mathrm{b}}$ & 103.68 & $103.45^{\mathrm{b}}$ \\
& $( \pm 8.41)$ & $( \pm 8.2)$ & $( \pm 9.74)$ & $( \pm 13.92)$ & $( \pm 11.23)$ & $( \pm 5.43)$ \\
\hline
\end{tabular}

${ }^{\mathrm{a}, \mathrm{b}}$ means within a column followed by the same letter are not significantly different $(\mathrm{P}>0.05)$.

Figure 2.2 presents blood glucose concentrations on days $28,56,84,112$, and 140 across feeding strategies. A greater blood glucose concentration was observed for NAT (113.70 mg/dL) versus CONV (109.79 mg/dL; $\mathrm{P}=0.02)$. The lowest blood glucose concentration was on day 28 and the greatest on day 112; however, days 56,84, and 140 were all similar (Figure 2.2). On day 84, the concentration of blood glucose was greater for the NAT feeding strategy than CONV (115.86 vs. $107.21 \mathrm{mg} / \mathrm{dL}$, respectively; $\mathrm{P}=0.02$; Figure 2.2). 
We reject our hypothesis suggesting that prolonged hyperglycemia may lead to IMF deposition due to the need for maintaining normal blood glucose concentration in ruminant species. Carcasses categorized with small degree of marbling had greater serum glucose than slightly abundant, which disapproves our hypothesis. However, this could be explained by the fact that steers with the marbling degree of slightly abundant had greater insulin concentration (Tables $2.7 \& 2.8$ ), which plays an important role on blood glucose uptake by hepatocytes or myocytes. Conversely, the NAT feeding strategy had greater blood glucose concentration than CONV (Figure 2.2), which also had greater degree of marbling (Table 2.4). This finding is in favor of our hypothesis. In addition, Buttery and Sinnett-Smith (1984) suggested that the use of anabolic steroids decreases the production of glucocorticoids, which is a group of hormones involved in carbohydrate metabolism (Moonsie-Shageer and Mowat, 1993). Therefore, this could explain why CONV steers had lower levels of glucose than NAT steers. Moreover, a study by Istasse et al. (1988) examined the use of 2 different doses of $17 \beta$-estradiol ( $E_{2}$; estrogenic implants) alongside with $200 \mathrm{mg}$ of trenbolone acetate (TBA; androgenic implant) on bulls from the Belgian Blue breed. The first group received no implants, the second group received $200 \mathrm{mg}$ of TBA and $40 \mathrm{mg}$ of $\mathrm{E}_{2}$ per implant, and the third group received $200 \mathrm{mg}$ of TBA and $60 \mathrm{mg}$ of $E_{2}$ per implant. Istasse et al. (1988) found that implanted bulls had lower blood glucose than untreated bulls, which was similar to the results in the present study. 


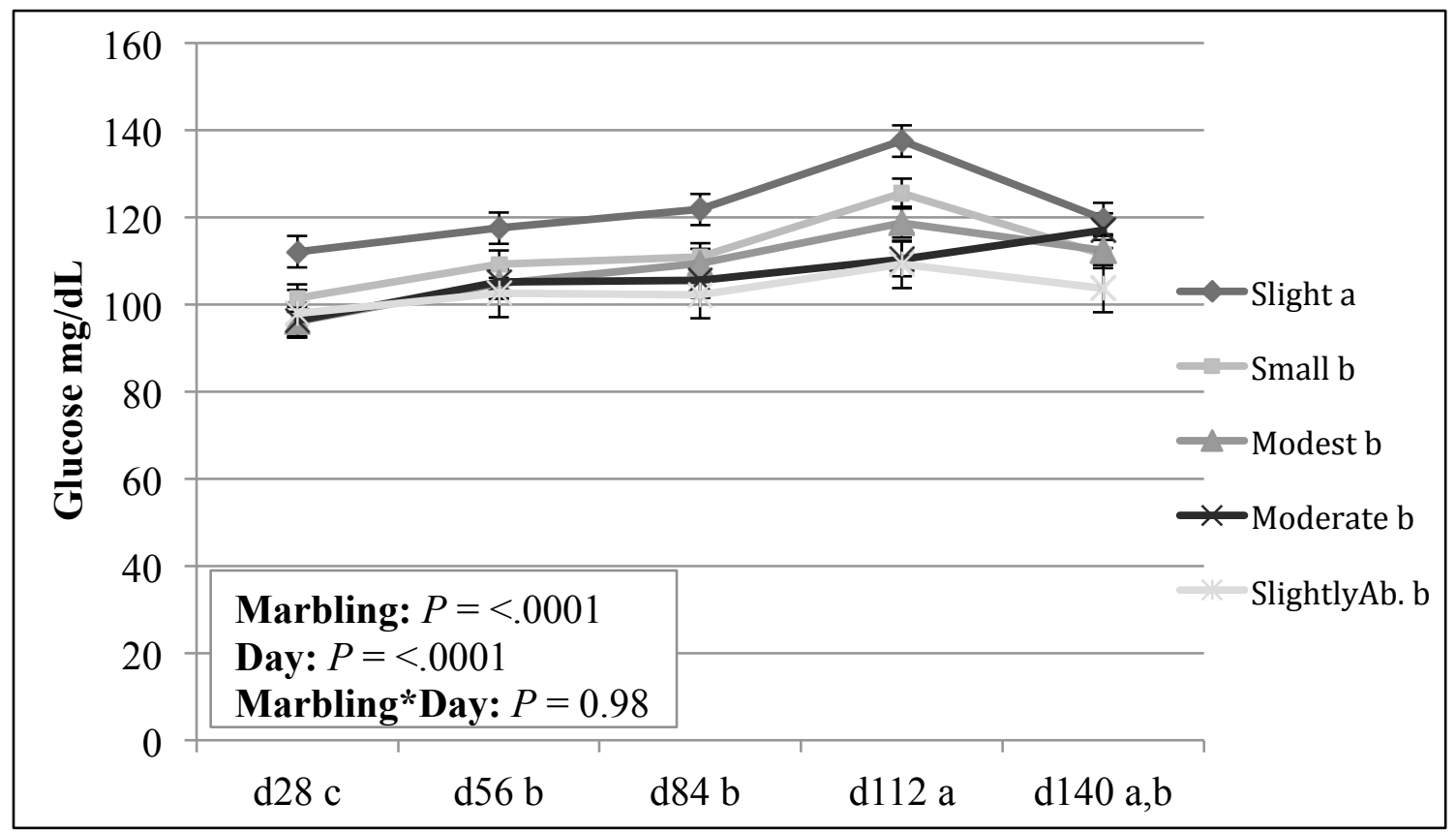

Figure 2.1. Serum glucose concentrations for degree of marbling, and for 140 days.

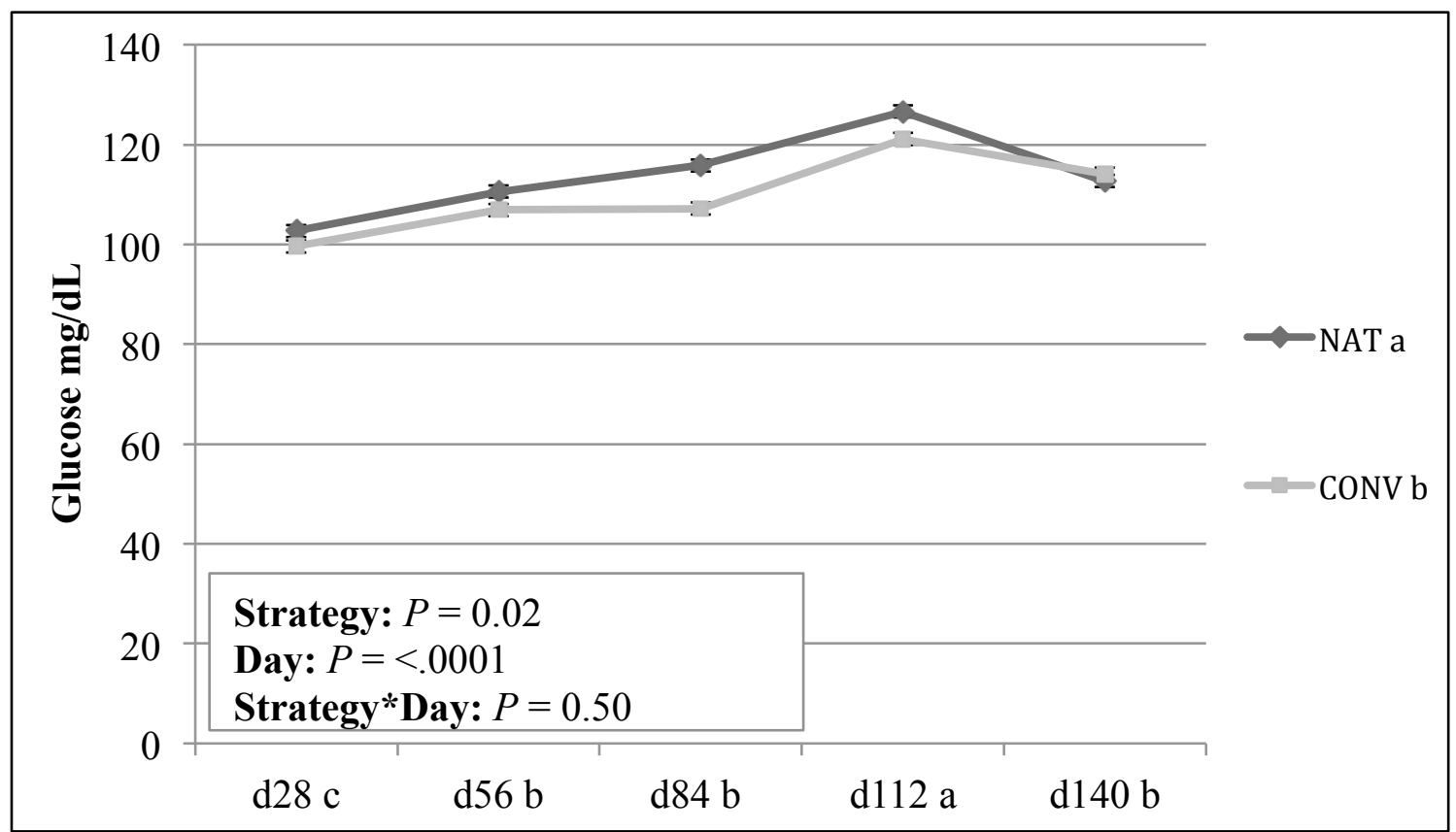

Figure 2.2. Serum glucose concentrations for feeding strategies, and for 140 days.

\section{Insulin Concentration}

Tables 2.8 and Figure 2.3 present the concentration of insulin in blood on days 28, 56, 84, 112, and 140 across marbling score categories. On day 112, steers delivering carcasses that fell 
in the moderate marbling score category had the greatest serum insulin concentrations, while the steers that ultimately had small marbling had the lowest concentrations (46.96 vs. $28.18 \mu \mathrm{U} / \mathrm{mL}$, respectively; $\mathrm{P}=0.03$ ). Moderate and small marbling classifications were similar in insulin concentrations compared to all other marbling scores. On days 28, 56, 84, and 140 the blood insulin concentrations were similar for all marbling scores. The average serum insulin concentrations of modest and moderate marbling scores were greater than small (33.18 and 36.59 vs. $26.84 \mu \mathrm{U} / \mathrm{mL}$, respectively; $\mathrm{P}=0.01$ ), however, both were similar to all other marbling scores (Table 2.8 and Figure 2.3).

Figure 2.4 presents the concentration of insulin in blood on days $28,56,84,112$, and 140 across feeding strategy. A greater blood insulin concentration was observed for CONV (32.78 $\mu \mathrm{U} / \mathrm{mL})$ versus NAT $(27.50 \mu \mathrm{U} / \mathrm{mL} ; \mathrm{P}=0.005)$. On day 28 , there was a tendency for the concentration of blood insulin with NAT to be greater than CONV (33.31 vs. $24.22 \mu \mathrm{U} / \mathrm{mL}$, respectively; $\mathrm{P}=0.06$ ). Moreover, on day $140, \mathrm{CONV}$ had a greater insulin concentration than NAT (35.97 vs. $25.47 \mu \mathrm{U} / \mathrm{mL}$, respectively; $\mathrm{P}=0.03$ ), however, on days 56,84 , and 112 the concentrations of insulin were similar.

The hormone insulin plays an important role in lipid metabolism by stimulating lipogenesis and glucose uptake from blood and inhibiting lipolysis. Moreover, it is obvious that hyperglycemia induces insulin secretion from pancreatic $\beta$-cells (Saltiel et al., 2001). Prolonged hyperglycemia leads to hyperinsulinemia, thus promoting insulin resistance. Insulin resistance occurs when, for example, myocytes cannot respond to insulin and therefore cannot receive glucose from bloodstream. In the case of muscle tissue specific insulin resistance, adipose tissues remain somewhat sensitive to insulin and continue to promote lipogenesis (Kitts et al., 2011). However, in our study, insulin concentrations did not dramatically change when degrees of 
marbling were compared against each other. The increase of insulin concentration in CONV steers when compared with NAT could be due to the utilization of the combination of estrogenic and androgenic implants in our study. Hayden et al. (1992) reported that the use of these implants in sheep increased the concentration of growth hormone (which promotes protein synthesis and inhibits fat synthesis) and thus, increased insulin concentration. In addition, a study by Grigsby and Trenkle (1986) examined the use of estradiol implants in Simmental steers and its effect on insulin concentration. Their study showed that implanted steers had greater insulin concentration than controls, which is similar to our result, which suggests that implants may increase insulin concentration.

Table 2.8. Insulin concentration $(\mu \mathrm{U} / \mathrm{mL})$ over day and marbling score.

\begin{tabular}{lcccccc}
\hline Marbling Score & $\mathbf{d 2 8}$ & $\mathbf{d 5 6}$ & $\mathbf{d 8 4}$ & $\mathbf{d 1 1 2}$ & $\mathbf{d 1 4 0}$ & Average \\
\hline \multirow{2}{*}{ Slight } & 26.34 & 31.06 & 26.14 & $35.12^{\mathrm{a}, \mathrm{b}}$ & 31.66 & $30.06^{\mathrm{a}, \mathrm{b}}$ \\
& $( \pm 5.92)$ & $( \pm 5.61)$ & $( \pm 4.2)$ & $( \pm 4.20)$ & $( \pm 6.14)$ & $( \pm 2.36)$ \\
Small & 25.26 & 27.46 & 26.54 & $28.18^{\mathrm{b}}$ & 26.79 & $26.84^{\mathrm{b}}$ \\
& $( \pm 3.7)$ & $( \pm 3.51)$ & $( \pm 2.58)$ & $( \pm 2.58)$ & $( \pm 3.66)$ & $( \pm 1.45)$ \\
Modest & 35.15 & 30.81 & 27.06 & $34.01^{\mathrm{a}, \mathrm{b}}$ & 38.9 & $33.18^{\mathrm{a}}$ \\
& $( \pm 4.5)$ & $( \pm 4.42)$ & $( \pm 3.16)$ & $( \pm 3.16)$ & $( \pm 4.62)$ & $( \pm 1.8)$ \\
Moderate & 29.6 & 42.65 & 38.56 & $46.96^{\mathrm{a}}$ & 25.18 & $36.59^{\mathrm{a}}$ \\
& $( \pm 8.3)$ & $( \pm 7.94)$ & $( \pm 5.75)$ & $( \pm 5.78)$ & $( \pm 8.44)$ & $( \pm 3.28)$ \\
\multirow{2}{*}{ Slightly $\mathrm{Ab}}$. & 36.09 & 24.85 & 34.14 & $44.32^{\mathrm{a}, \mathrm{b}}$ & 27.92 & $33.46^{\mathrm{a}, \mathrm{b}}$ \\
& $( \pm 12.5)$ & $( \pm 11.91)$ & $( \pm 8.67)$ & $( \pm 10.01)$ & $( \pm 12.66)$ & $( \pm 5.00)$ \\
\hline
\end{tabular}

${ }^{\mathrm{a}, \mathrm{b}}$ means within a column followed by the same letter are not significantly different $(\mathrm{P}>0.05)$. 


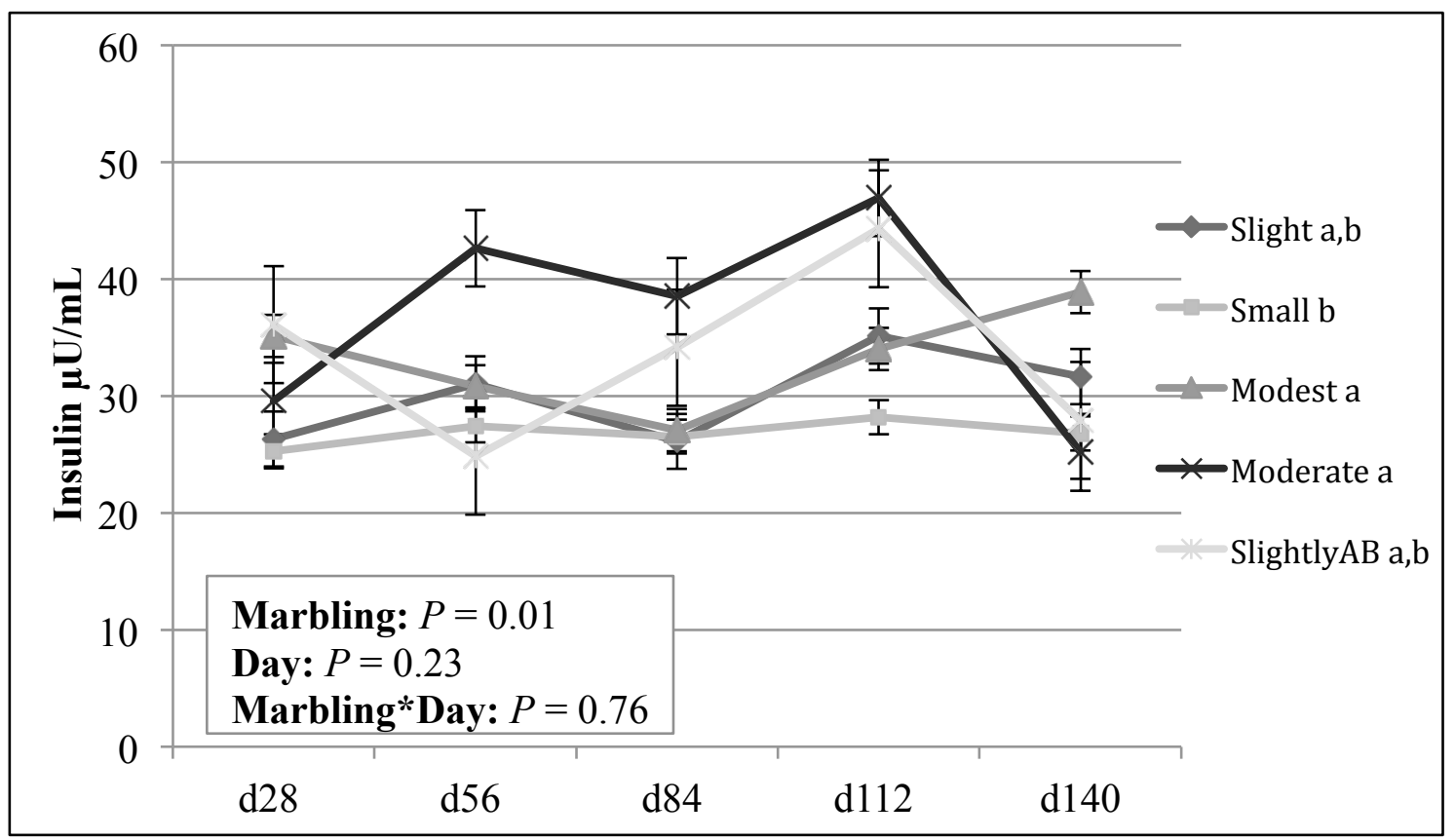

Figure 2.3. Serum insulin concentrations for degree of marbling, and for 140 days.

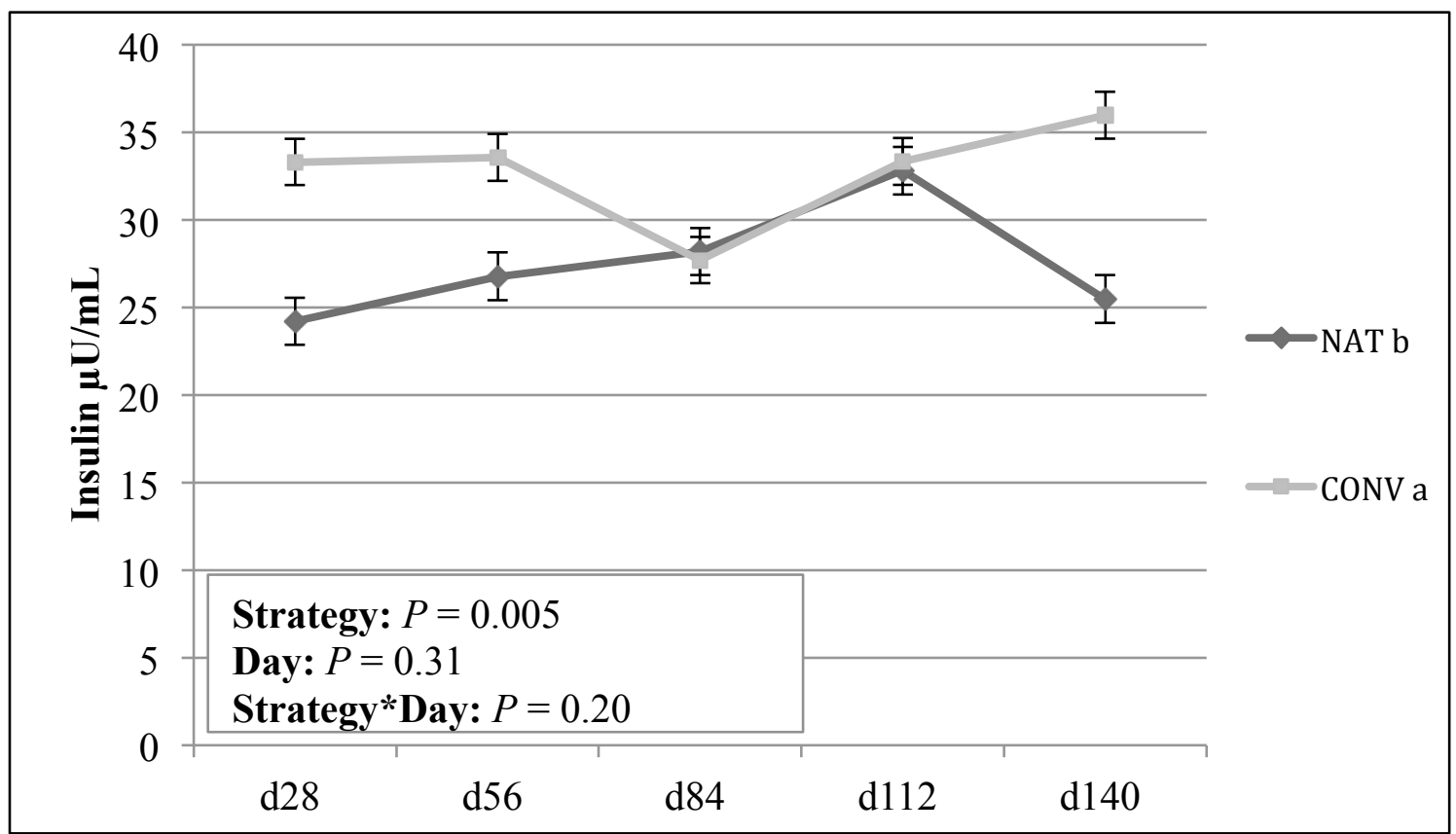

Figure 2.4. Serum insulin concentrations for feeding strategies, and for 140 days.

\section{Conclusion}

Total serum protein and serum albumin did not change between feeding strategies or between marbling scores. Moreover, glycated albumin products did not correlate with degree of 
marbling. The feeding strategy CONV had greater T-GA and P-GA than NAT. Both T-GA and P-GA did not differ between marbling scores and did not correlated with marbling score. However, both T-GA and P-GA showed a negative correlation with the KPH and FD12 fat depots, which were positively correlated with marbling score. Despite the negative correlation between T-GA and P-GA with both KPH and FD12, no evidence was found to indicate an association between concentration of glycated albumin and degree of marbling category. More research is necessary to evaluate physiological changes associated with marbling deposition in beef cattle.

\section{Acknowledgements}

The North Dakota State Board of Agriculture Research and Education, the North Dakota Beef Commission, and the North Dakota Agriculture Experiment Station partially funded this project.

\section{Literature Cited}

Abidin, D., Liu, L., Dou, C., Datta, A., \& Yuan, C. (2013). An improved enzymatic assay for glycated serum protein. Analytical Methods, 5(10), 2461-2469.

Adachi, K., Kawano, H., Tsuno, K., Nomura, Y., Katsura, N., Arikawa, A., ... Onimaru, T. (1997). Values of the serum components in Japanese black beef steers at farms with high productivity and low frequencies of disease and death in Miyazaki Prefecture. Journal of Veterinary Medical Science, 59(10), 873-877.

Buttery, P. J., \& Sinnett-Smith, P. A. (1984). The mode of action of anabolic agents. In Manipulation of Growth in Farm Animals (pp. 211-228). Springer.

Carmen, G.-Y., \& Víctor, S.-M. (2006). Signalling mechanisms regulating lipolysis. Cellular Signalling, 18(4), 401-408. 
Choi, S., Choi, E. Y., Kim, D. J., Kim, J. H., Kim, T. S., \& Oh, S. W. (2004). A rapid, simple measurement of human albumin in whole blood using a fluorescence immunoassay (I). Clinica Chimica Acta, 339(1), 147-156.

Doornenbal, H., Tong, A. K., \& Murray, N. L. (1988). Reference values of blood parameters in beef cattle of different ages and stages of lactation. Canadian Journal of Veterinary Research, 52(1), 99.

Doumas, B. T. (1975). Standards for total serum protein assays - a collaborative study. Clinical Chemistry, 21(8), 1159-1166.

Evans, D. J., Murray, R., \& Kissebah, A. H. (1984). Relationship between skeletal muscle insulin resistance, insulin-mediated glucose disposal, and insulin binding. Effects of obesity and body fat topography. Journal of Clinical Investigation, 74(4), 1515.

Grigsby, M. E., \& Trenkle, A. (1986). Plasma growth hormone, insulin, glucocorticoids and thyroid hormones in large, medium and small breeds of steers with and without an estradiol implant. Domestic Animal Endocrinology, 3(4), 261-267.

Grünwaldt, E. G., Guevara, J. C., Estevez, O. R., Vicente, A., Rousselle, H., Alcuten, N., ... Stasi, C. R. (2005). Biochemical and haematological measurements in beef cattle in Mendoza plain rangelands (Argentina). Tropical Animal Health and Production, 37(6), $527-540$.

Haffner, S. M. (2003). Insulin resistance, inflammation, and the prediabetic state. The American Journal of Cardiology, 92(4), 18-26.

Haffner, S. M., Valdez, R. A., Hazuda, H. P., Mitchell, B. D., Morales, P. A., \& Stern, M. P. (1992). Prospective analysis of the insulin-resistance syndrome (syndrome X). Diabetes, 41(6), 715-722. 
Hayden, J. M., Bergen, W. G., \& Merkel, R. A. (1992). Skeletal muscle protein metabolism and serum growth hormone, insulin, and cortisol concentrations in growing steers implanted with estradiol-17 beta, trenbolone acetate, or estradiol-17 beta plus trenbolone acetate. Journal of Animal Science, 70(7), 2109-2119.

Hood, R. L. (1982). Relationships among growth, adipose cell size, and lipid metabolism in ruminant adipose tissue. In Federation proceedings (Vol. 41, pp. 2555-2561).

Istasse, L., Evrard, P., Eenaeme, C. Van, Gielen, M., Maghuin-Rogister, G., \& Bienfait, J.-M. (1988). Trenbolone Acetate in Combination with 17-Estradiol: Influence of Implant Supports and Dose Levels on Animal Performance and Plasma Metabolites. Journal of Animal Science, 66(5), 1212-1222.

Jones, S. J., Starkey, D. L., Calkins, C. R., \& Crouse, J. D. (1990). Myofibrillar protein turnover in feed-restricted and realimented beef cattle. Journal of Animal Science, 68(9), 27072715.

Kaneko, J. J., Harvey, J. W., \& Bruss, M. L. (2008). Clinical biochemistry of domestic animals. Academic press.

Kitts, S. E. (2011). EFFECTS OF ADIPOGENIC COMPOUNDS ON GROWTH PERFORMANCE AND FAT DEPOSITION IN FINISHING BEEF STEERS.

Koga, M., Murai, J., Saito, H., Mukai, M., \& Kasayama, S. (2010). Serum glycated albumin, but not glycated haemoglobin, is low in relation to glycemia in hyperuricemic men. Acta Diabetologica, 47(2), 173-177.

Koupparis, M. A., Diamandis, E. P., \& Malmstadt, H. V. (1985). Automated stopped-flow analyser in clinical chemistry: determination of albumin with bromcresol green and purple. Clinica Chimica Acta, 149(2), 225-235. 
Moonsie-Shageer, S., \& Mowat, Dn. (1993). Effect of level of supplemental chromium on performance, serum constituents, and immune status of stressed feeder calves. Journal of Animal Science, 71(1), 232-238.

Muñoz, R., Tor, M., \& Estany, J. (2012). Relationship between blood lipid indicators and fat content and composition in Duroc pigs. Livestock Science, 148(1), 95-102.

Saltiel, A. R., \& Kahn, C. R. (2001). Insulin signalling and the regulation of glucose and lipid metabolism. Nature, 414(6865), 799-806.

Van der Vusse, G. J. (2009). Albumin as fatty acid transporter. Drug Metabolism and Pharmacokinetics, 24(4), 300-307.

Wellnitz, K. 2014. Body weight and adiposity changes of obese gilts provided ad libitum ground beef versus high carbohydrate diets. M.S. Thesis. North Dakota State University: U.S.

Zheng, C.-M., Ma, W.-Y., Wu, C.-C., \& Lu, K.-C. (2012). Glycated albumin in diabetic patients with chronic kidney disease. Clinica Chimica Acta, 413(19), 1555-1561.

Zilg, H., Schneider, H., \& Seiler, F. R. (1979). Molecular aspects of albumin functions: indications for its use in plasma substitution. Developments in Biological Standardization, 48, 31-42. 